\title{
Effects of frequent fire and mowing on resprouting shrubs of Florida scrub, USA
}

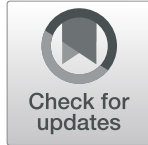

Eric S. Menges ${ }^{1 *}$, Stacy A. Smith ${ }^{1}$, Jose M. Olano², Jennifer L. Schafer ${ }^{3}$, Gretel Clarke ${ }^{1}$ and Kevin Main ${ }^{1}$

\begin{abstract}
Background: Resprouting is an effective strategy for persistence of perennial plants after disturbances such as fire. However, can disturbances be so frequent that they limit resprouting? We examined the effects of fire and mowing frequency on eight species of resprouting shrubs in Florida scrub, USA, using a factorial field experiment. We burned or mowed plots at four disturbance return intervals (DRI): either annually, biennially, every three years, or once in six years (with all plots being treated in the sixth year to control for time since disturbance). We analyzed plant growth responses (height, aboveground biomass, number of stems) based on sampling pre treatment, and six months, one year, two years, and four years post-treatment. We also measured non-structural carbohydrates (NSC) and soil properties to evaluate these factors as potential drivers of resprouting responses.

Results: Fire temperatures were hot (mean maxima 414 to $698^{\circ} \mathrm{C}$ among burn days), typical of larger fires in Florida scrub. Plant biomass and heights were affected by DRI (being suppressed by frequent disturbance, especially initially) and varied among species with palmettos recovering biomass faster, and species within the same genus generally showing similar responses. Biomass recovery in mown versus burned treatments showed comparable effects of DRI and similar trajectories over time. Numbers of stems were affected by DRI, disturbance type, and species, and increased after disturbances, especially with less frequent disturbances and mowing, and subsequently declined over time. NSC concentrations varied among species and over time and were positively related to biomass. One year post disturbance, soil moisture and organic matter content were higher in mown plots, while pH was higher in burned plots. Given the slightly lower elevation of the mown plots, we interpreted these differences as site effects. Soil properties were not affected by DRI and did not affect biomass responses.

Conclusions: Although very frequent disturbances reduced shrub growth responses, the magnitude of plant responses was modest and the effects temporary. Because resprouting shrubs in Florida scrub appear resilient to a range of disturbance return intervals, frequent fire or mowing can be used effectively in restorations.
\end{abstract}

Keywords: biomass dynamics, carbohydrates, disturbance return interval, fire, oaks, palmettos, soil nutrients, temperatures

\footnotetext{
* Correspondence: emenges@archbold-station.org

${ }^{1}$ Archbold Biological Station, 123 Main Drive, Venus, Florida 33960, USA

Full list of author information is available at the end of the article
}

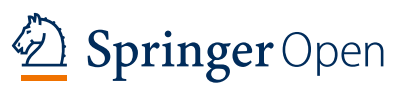

(c) The Author(s). 2020 Open Access This article is licensed under a Creative Commons Attribution 4.0 International License, which permits use, sharing, adaptation, distribution and reproduction in any medium or format, as long as you give appropriate credit to the original author(s) and the source, provide a link to the Creative Commons licence, and indicate if changes were made. The images or other third party material in this article are included in the article's Creative Commons licence, unless indicated otherwise in a credit line to the material. If material is not included in the article's Creative Commons licence and your intended use is not permitted by statutory regulation or exceeds the permitted use, you will need to obtain permission directly from the copyright holder. To view a copy of this licence, visit http://creativecommons.org/licenses/by/4.0/. 


\section{Resumen}

Antecedentes: El rebrote es una estrategia efectiva de persistencia de plantas perennes luego de disturbios como el fuego. Sin embargo, ¿pueden diferentes frecuencias en la ocurrencia de estos disturbios limitar el rebrote? Examinamos los efectos del fuego y la frecuencia de corte en ocho especies arbustivas rebrotantes en matorrales de Florida, EEUU, usando un experimento a campo de diseño factorial. Quemamos o cortamos parcelas en cuatro intervalos de tiempo de retorno diferentes (DRI): anualmente, bienalmente, trienalmente y una vez en seis años (con todas las parcelas tratadas en el año seis para controlarlas desde el inicio de los tratamientos). Analizamos las respuestas de las plantas al crecimiento (altura, biomasa aérea, número de tallos), basados en los muestreos de pretratamientos y seis meses, un año, dos años, y cuatro años post-tratamientos. También medimos carbohidratos no estructurales (NSC) y propiedades del suelo para evaluar esos factores como potenciales promotores de las respuestas de los rebrotes.

Resultados: Las temperaturas del fuego fueron altas (máxima media de entre 414 a $698{ }^{\circ} \mathrm{C}$ entre días de quemas), típicas de grandes incendios de matorrales de Florida. La biomasa de plantas y sus alturas fueron afectadas por el DRI (siendo suprimidas por los disturbios frecuentes, especialmente al inicio de los tratamientos) y variaron entre especies, con la palma de abanico recuperando su biomasa de manera más rápida y especies del mismo género generalmente mostrando respuestas similares. La recuperación de la biomasa en rebrotes cortados versus quemados mostró efectos comparables en DRI y trayectorias similares en el tiempo. El número de tallos fue afectado por el DRI, el tipo de disturbio, y las especies consideradas, y se incrementaron luego de los disturbios, especialmente con disturbios menos frecuentes y corte, y subsecuentemente declinaron en el tiempo. La concentración de carbohidratos no estructurales (NSC) varió entre especies y en el tiempo, y fue positivamente relacionada con la biomasa. Un año después de los disturbios, la humedad del suelo y el contenido de material orgánica de los suelos fue mayor en los tratamientos de corte, mientras que el pH fue mayor en los tratamientos de quema. Dada la menor altura de los tratamientos de corte, interpretamos esas diferencias como efectos de sitio. Las propiedades del suelo no fueron afectadas por el DRI y no afectó las respuestas en biomasa.

Conclusiones: Aunque disturbios muy frecuentes reducen las respuestas del crecimiento, la magnitud de las respuestas fue modesta y de efectos temporarios. Dado que los arbustos rebrotantes en matorrales de Florida aparecen como resilientes a un rango de distintos intervalos de disturbios, las quemas frecuentes o los cortes de tallos pueden ser usados efectivamente en tareas de restauración.

\section{Abbreviations}

ABS: Archbold Biological Station

ANOVA: ANalysis Of VAriance

BU: $\quad$ Burn Unit

DRI: Disturbance Return Interval

NSC: Non-Structural Carbohydrates

SOM: Soil Organic Matter

\section{Background}

Resprouting from belowground bud banks is a widespread persistence strategy (Bond and Midgley 2001) for plants to recover from fire (Pausas et al. 2018), drought (Zeppel et al. 2015), herbivory (LaPointe et al. 2010), and other ecological disturbances (Bellingham and Sparrow 2000; Poorter et al. 2010; Klimesova et al. 2017). In fact, periodic fires may favor resprouting plants over non-resprouting taxa. Fire regimes (including fire frequency, fire intensity, and seasonality) impose selective pressures on plant life histories. In particular, the ability to resprout may be a general response to disturbances but could also be selected for by fire regimes. For example, resprouting (versus seeding) can be selected for by frequent fires, although this varies among regions (Pausas et al. 2004; Lamont et al. 2011). However, very frequent fires (or other disturbances) can exhaust resprouters' carbohydrate reserves, shifting vegetation from resprouters to obligate seeders (Clarke et al. 2015). Severe fires may kill buds near the soil surface and disadvantage resprouters, favoring obligate seeders (Lamont et al. 2011; Clarke et al. 2013). Assessing fire frequency and other components of the fire regime, in relation to plant life history traits, is one way to infer an evolutionarily relevant fire regime. This can be used to set fire regime boundaries for fire management planning. Fire regime limits often involve minimum inter-fire intervals for obligate seeders (Russell-Smith et al. 2002), but do not often consider fire return interval limits for resprouting plants (Clarke et al. 2013).

Resprouting success involves resprouting ability, resprouting vigor, and post-resprouting survival (Moreira et al. 2012). Resprouting vigor and post-disturbance growth depend on storage of non-structural carbohydrates (NSC), nutrient availability, availability of bud banks, fire temperature, and fire duration. Large NSC reserves (especially starch) support post-disturbance 
resprouting, survival, and growth (e.g., Huddle and Pallardy 1999; LaPointe et al. 2010), while repeated aboveground biomass removal can deplete starch reserves and increase shrub mortality (Canadell and Lopez-Soria 1998; Paula and Ojeda 2009). Sequential disturbances such as hailstorms followed by fire can reduce resprouting of Australian shrubs (Gower et al. 2015). Soil nutrients affect resprouting vigor, with vigor generally increasing with nitrogen (Cruz et al. 2003) or phosphorus fertilization (Sardans et al. 2006). Fire severity influences resprouting success through its effect on bud banks; resprouting percentages are higher at intermediate fire severities (Nicholson et al. 2017). Furthermore, slower regrowth of resprouts occurs after high fire intensities (Moreno and Oechel 1991; Thaxton and Platt 2006).

Hydrology may interact with fire to affect resprouting responses. For example, in some ecosystems where fire is not common, drought may interact with fire to increase mortality of resprouting species (Van Nieuwstdt and Sheil 2005). After fire in riparian vegetation in the southwestern US, resprout survival was highest in areas with shallower water tables (Smith et al. 2009). However, resprouting plants are generally capable of withstanding drought and recovering rapidly after top removal (Zeppel et al. 2015).

Experiments on the effects of disturbances on resprouting commonly include clipping aboveground plant parts (e.g., Cruz et al. 2003; Schafer and Just 2014; Martinez-Vilalta et al. 2016). If the main effect of repeated loss of aboveground biomass is carbohydrate starvation, then clipping and burning should have similar effects on resprouting (Hmielowski et al. 2014; Michielsen et al. 2017). If resprouting responses are stronger in relation to fire than clipping (e.g., Peguero and Espelta 2011; Noble and Diggle 2014), this could be attributed to the positive effects of nutrient fertilization from ash, loss of nutrients through volatilization, or direct effects of heat on bud banks. In a study of semi-arid plants in Australia, one fifth of species were stronger resprouters after clipping than burning, while other resprouting species responded similarly to the two disturbances (Vesk et al. 2004).

The main ecological disturbance in Florida ecosystems is lightning-ignited fires, which are especially common during the late spring (Platt et al. 2015; Noss 2018). Prescribed fire started as early as 1960 in parts of Florida (Glitzenstein et al. 2012); currently, Florida burns more area than any other state. Prescribed fire councils are found throughout Florida, and Florida's landmark Prescribed Burning Act provides legal protection to landowners and others conducting prescribed burns (Brenner and Wade 2003). Fire ecology research in Florida has focused on such topics as fire effects on vegetation (Abrahamson 1984; Myers 1985; Menges and Kohfeldt 1995), season of burn effects (Robbins and Myers 1992), fire ecology of endangered plants and animals (Breininger et al. 1995;
Menges 1999; Menges et al. 2006; Ashton et al. 2008), fire effects on species interactions (Knight and Holt 2005), and fire effects on ecosystem properties (Schmalzer and Hinkle 1996; Schafer and Mack 2018). Generally, these studies show that plant species vary in their responses to fire; that frequencies can increase, decrease, or be unchanged with time since fire; that many rare species depend on fire to maintain viable populations; and that fire affects nutrient availability without shifting nutrient limitation of primary productivity.

We conducted our research in scrubby flatwoods (Fig. 1), a type of Florida scrub, which is a shrub-dominated ecosystem where fire is the main ecological disturbance (Menges 2007). Fires are generally intense enough to top-kill all stems of scrub oaks (Quercus spp. L.) and other shrubs (Abrahamson 1984; Menges 1999). Most dominant plants in scrubby flatwoods are strong resprouters post fire (Menges and Kohfeldt 1995). Although frequent fires can have positive or negative effects on obligate-seeder species in Florida scrub (Menges et al. 2006; Menges 2007), the effects of frequent fires on resprouting species have not been well explored. In other ecosystems, frequent fires may reduce shrub dominance (Roques et al. 2001; Briggs et al. 2002). Reductions in shrub dominance may be related to changes in carbohydrate dynamics with frequent fire (Enright et al. 2011). A previous study in Florida scrub found that NSC levels tended to increase with time since fire in dominant shrubs and decrease in subordinate shrubs (Olano et al. 2006), suggesting that species will respond differently to changes in fire frequency.

The goal of this study was to assess the effects of disturbance return interval (DRI) and disturbance type (burning, mowing) on resprouting and growth of eight resprouting shrub species. We conducted a six-year field experiment manipulating disturbance frequencies. Prescribed fire and mowing (i.e., clipping) occurred at four different disturbance return intervals. All plots were disturbed in the sixth year, keeping subsequent time since disturbance constant. After the treatments were completed, we monitored growth responses of shrub species for four years. We also collected data on non-structural carbohydrates and soil characteristics to determine if these were drivers of the vegetation response. We hypothesized that: (1) frequent disturbances would reduce resprouting responses due to depletion of belowground reserves; (2) plants would grow faster after fire than after mowing due to nutrient fertilization from ash; and (3) resprouting would be more vigorous for plants with high carbohydrate reserves and in soils with higher water and soil nutrient availability.

\section{Methods}

Study site and species

We worked at Archbold Biological Station (ABS; Swain 1998), a research facility in south-central Florida, USA 


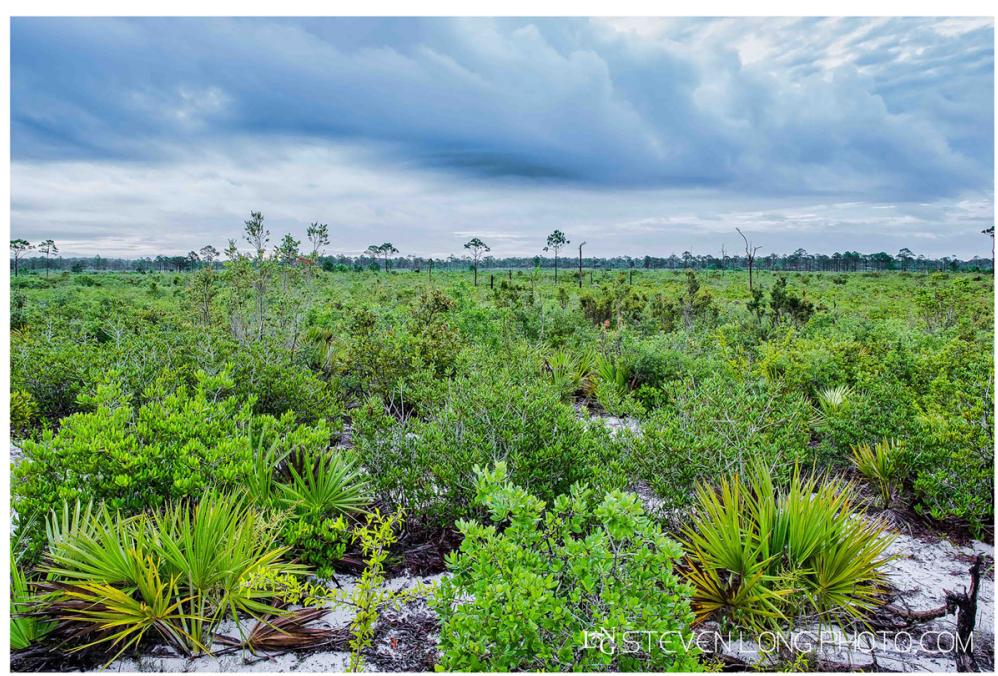

Fig. 1 View of scrubby flatwoods in 2016 at Archbold Biological Station, Lake Placid, Florida, USA, five years post fire. Visible are evergreen oaks (Quercus chapmanii, Q. inopina), palmettos (Sabal etonia, Serenoa repens), and the ericaceous shrub Lyonia fruticosa. Photo by Steve Long, used with permission

$\left(27.17^{\circ} \mathrm{N}, 81.35^{\circ} \mathrm{W}\right) . \mathrm{ABS}$ is one of the largest remaining protected tracts on Lake Wales Ridge (Weekley et al. 2008) and a hotspot for endemism (Estill and Cruzan 2001; Turner et al. 2006). ABS includes over 2100 ha of Florida scrub, southern ridge sandhill, flatwoods, and seasonal pond habitats (Abrahamson et al. 1984).

We located the experiment in scrubby flatwoods (Fig. 1), a type of Florida scrub found on coarse sands (Abrahamson et al. 1984; Menges 1999). Our study site was on Duette sand (a hyperthermic, Grossarenic Entic Haplohumod), a moderately well drained soil with low water-holding capacity (Carter et al. 1989). Scrubby flatwoods are dominated by resprouting shrubs (Menges and Kohfeldt 1995; Maguire and Menges 2011; Schafer and Mack 2013) and have fewer and smaller gaps than neighboring rosemary scrub (Dee and Menges 2014). Scrubby flatwoods have low nutrient availability (Schafer and Mack 2013) but show little evidence of nutrient limitation during the first year after fire (Schafer and Mack 2018), suggesting that post-fire increases in nutrient availability (Lavoie et al. 2010; Schafer and Mack 2010; Ficken and Wright 2017) may be important for supporting resprouting and subsequent shrub growth in scrubby flatwoods.

The fire regime in scrubby flatwoods is characterized by high-intensity crown fires moving through shrub canopies. The presumed natural fire return interval is 8 to 16 years (Menges 2007; Menges et al. 2017). Fires were historically ignited by lightning during the growing season, especially in late spring (Platt et al. 2015; Noss 2018). At ABS, fires vary in severity and patchiness due to vegetation type but not weather or season (Menges et al. 2017). Fire temperatures are high, with maximum temperatures reaching $488{ }^{\circ} \mathrm{C}$, oneminute mean temperatures ranging from 265 to $330{ }^{\circ} \mathrm{C}$, and mean residence times (minutes above $60{ }^{\circ} \mathrm{C}$ ) ranging from 5 to 14.7 minutes (Wally et al. 2006; Dean et al. 2015).

We chose a single burn unit (BU 30A) at ABS, which last burned in 1994 (11 years before the study initiation) with sufficient intensity to top-kill all shrubs. We studied eight of the most common shrub species found in scrubby flatwoods at ABS: three oak species (Quercus inopina Ashe, Q. geminata Small, Q. chapmanii Sarg.), three ericaceous shrubs (Lyonia fruticosa [Michx.] G.S. Torr., L. lucida [Lam.] K. Koch, and Vaccinium myrsinites [Lam.]), and two palmettos (Sabal etonia Swingle ex Nash, and Serenoa repens [W. Bartram] Small). Other prominent species at this site ( $V$. darrowii Camp, Gaylussacia dumosa Andrews [A. Gray], Palafoxia feayi A. Gray, Aristida stricta Michx., Bejaria racemosa Vent., Chapmannia floridana Torr. \& A. Gray, and Rhynchospora megalocarpa A. Gray) did not have enough stems distributed throughout the site to use in the experiment. Sand pine (Pinus clausa [Chapm. ex Engelm.] Vasey ex Sarg.) was an important tree in nearby areas but was sparse at our study site.

\section{Experimental design}

To explore the effects of disturbance return interval (DRI) and disturbance type (burning, mowing) on resprouting and growth of eight shrub species, we designed our experiment to separate effects of time since disturbance from DRI. Over a period of six years (2005 to 2010), plots were burned or mowed once, twice, three 
times, or six times. The burning and mowing treatments were arranged so that every plot was burned or mowed in 2010, the sixth year of the study (Table 1). This kept all plots at the same time since disturbance following the application of the final treatment in 2010 and allowed the analyses to focus on effects of DRI on resprouting responses.

\section{Study site and plot set-up}

We had four replicates of each disturbance type (fire, mowing) and DRI (1, 2, 3, and 6 years) combination, resulting in 32 total plots. The 32 plots were set up in two groups of 16. To avoid potential effects of burns on mowed plots, the two types of plots were separated by about $20 \mathrm{~m}$. The 16 burned plots were in one line oriented north to south, and the 16 mowed plots were in a second line upwind (to the east) of the burned plots. Each plot was $20 \times 5 \mathrm{~m}$, with a $15 \times 1 \mathrm{~m}$ belt transect centered within the plot, which was used for vegetation measurements. The long axis of each plot was oriented east to west (in the direction of the most common wind) so that head fires would occur with moderate intensity. All plots were $>20 \mathrm{~m}$ from the nearest sand road. To restrict fire to appropriate areas, we used mowing to create $5 \mathrm{~m}$ firebreaks around each plot and $>10 \mathrm{~m}$ firebreaks around the entire study area.

\section{Burning and mowing treatments}

DRIs were assigned randomly and independently for burned and mowed plots. Fires were set with drip torches in individual plots according to the experimental design (Table 1). We generally used easterly winds to burn the plots toward the road on the western boundary of the burn unit, sending ash away from the mowed plots. If there was insufficient fuel due to repeated burns, we added fuel that had been mown from the adjacent firebreaks (especially palmetto leaves and pine needles). Fires were lit repeatedly to burn $100 \%$ of all burnassigned plots. Fires were allowed to burn out before any water was used in mop-up. All fires were conducted

Table 1 Disturbance schedule for all plots, Archbold Biological Station, Venus, Florida, USA, 2005 to 2010. All disturbances (burning or mowing) were accomplished in March or April each year. Disturbance treatments were designed so that all plots were burned or mown in 2010, holding time since disturbance constant. Plot assignments to treatments were made randomly within burn or mown areas

\begin{tabular}{ll}
\hline Disturbance frequency & Years of disturbance \\
\hline Annually & $2005,2006,2007,2008,2009,2010$ \\
Every $2 \mathrm{yr}$ & $2006,2008,2010$ \\
Every $3 \mathrm{yr}$ & 2007,2010 \\
Once in $6 \mathrm{yr}$ & 2010 \\
\hline
\end{tabular}

in the spring months (Table 2), were successful in burning the plots without escapes, and top-killed nearly all shrub stems.

We mowed plots according to the same schedule as burning (Table 1), a few days after each burn was accomplished. We used a Brown tree cutter (Brown Manufacturing Corporation, Ozark, Alabama, USA) and mowed to a height of about $10 \mathrm{~cm}$. Mowed vegetation was left in the plots.

\section{Fire measurements}

During each fire, we measured fire temperatures using HOBO temperature dataloggers (Type $\mathrm{K}$ thermocouple logger part H12002, Onset Computer Corporation, Bourne, Massachusetts, USA). Prior to the fires, dataloggers were buried $10 \mathrm{~cm}$ below the soil surface with double stranded wire leads exposed at the soil surface (beneath any litter; there was no duff in these plots). Dataloggers were installed at $5 \mathrm{~m}$ intervals along the long axis of each plot within the belt transect. Dataloggers were programmed to save temperatures every $2 \mathrm{~s}$. From the raw data, we derived maximum temperatures, maximum one-minute mean temperatures, and residence times (minutes above $60{ }^{\circ} \mathrm{C}$ ). We also estimated flame lengths and recorded weather data (relative humidity, temperature, wind speed, wind direction) during fires.

\section{Vegetation measurements and analysis}

We collected vegetation data on the eight most common resprouting shrubs from belt transects centered within the plots. We counted the number of stems (ramets) of each target species in the belt transect. In addition, at each $1 \mathrm{~m}$ interval, we selected the nearest ramet of each target species (if within $50 \mathrm{~cm}$ of the transect) and measured its height and maximum crown diameter (to the nearest centimeter). If we did not find at least five ramets of a species using this sampling method, we randomly measured additional ramets within the plot to bring sample sizes to five. Ramet location was determined by rooting position (ground level). We estimated aboveground biomass from height and crown diameter using regressions developed from harvests of these species at ABS (Menges and Smith 2019). For the current study, we chose regression equations for plants collected across a range of times since fire.

We sampled vegetation pre treatment in spring 2005 and 6 mo (October 2010), 1 yr (April 2011), 2 yr (April 2012), and 4 yr (April 2014) after treatments ended. We analyzed biomass, height, and number of stems (all $\mathrm{ln}$ transformed) in relation to species, DRI, and disturbance type (and their interactions) in repeated measures analysis of variance (ANOVA). We chose the univariate procedure as it is more powerful than the multivariate procedure (Potvin et al. 1990; von Ende 1993). For 
Table 2 Information on fire dates that made up the experimental treatments. Weather data were taken onsite or from a weather station located $700 \mathrm{~m}$ away from the study location at Archbold Biological Station, Venus, Florida, USA, from 2005 to 2010. Wind data were taken at ground level near fire. Fuels were added to reburned plots from 2006 onward. All fires occurred between 0945 and 1300 hours. $N=$ number of plots burned. KBDI = Keetch-Byram Drought Index (Keetch and Byram 1968). Min Rh = minimum relative humidity. Max AT = maximum air temperature. Max WS = maximum wind speed. Max FT = the mean of the maxima among the dataloggers per plot. Max 1-min mean = the mean of the maximum 1-minute means among dataloggers per plot. Mean RT = the number of minutes that temperature recorded above $60^{\circ} \mathrm{C}$. FL = flame length of typical flames (maximum observed length in parentheses). Days since rain and days to next rain were taken from Archbold Biological Station weather data (main weather station)

\begin{tabular}{|c|c|c|c|c|c|c|c|c|c|c|c|c|}
\hline Year & Date & $N$ & $\mathrm{KBDI}$ & Min Rh (\%) & Max AT $\left({ }^{\circ} \mathrm{C}\right)$ & $\begin{array}{r}\text { Max WS } \\
\left(\mathrm{km} \mathrm{hr}^{-1}\right)\end{array}$ & Max FT $\left({ }^{\circ} \mathrm{C}\right)$ & $\begin{array}{r}\text { Max 1-min } \\
\text { mean }\left({ }^{\circ} \mathrm{C}\right)\end{array}$ & Mean RT (min) & $\mathrm{FL}(\mathrm{m})$ & $\begin{array}{l}\text { Days since } \\
\text { rain }\end{array}$ & $\begin{array}{l}\text { Days to } \\
\text { next rain }\end{array}$ \\
\hline 2005 & $20 \mathrm{Apr}$ & 4 & 438 & 46 & 26 & 8 & 698 & 531 & 5.4 & 1 to 2 (5) & 6 & 7 \\
\hline 2006 & 30 Mar & 8 & 527 & 41 & 28 & 14 & 486 & 368 & 10.5 & 1 to $3(6)$ & 5 & 11 \\
\hline 2007 & $20 \mathrm{Apr}$ & 8 & 597 & 30 & 29 & 19 & 525 & 301 & 5.6 & 2 to 4 (6) & 4 & 14 \\
\hline 2008 & $26 \mathrm{Mar}$ & 8 & 482 & 50 & 23 & 11 & 414 & 263 & 5.1 & NA & 2 & 5 \\
\hline 2009 & 17 Mar & 4 & 705 & 46 & 28 & 11 & 478 & 426 & 22.9 & 2 to $3(4)$ & 15 & 1 \\
\hline 2010 & $16 \mathrm{Apr}$ & 16 & 257 & 38 & 27 & 19 & 578 & 399 & 11.5 & NA & 1 & 21 \\
\hline
\end{tabular}

univariate repeated measures ANOVA, we used Mauchly's W test for sphericity (Mauchly 1940). Since the assumption of sphericity was never met, degrees of freedom were adjusted using the Greenhouse-Geisser estimated epsilon values (Potvin et al. 1990). We also used repeated measures ANOVA to analyze treatment effects on individual species' biomass as well. We evaluated the repeated measures ANOVAs using Roy's largest root, which represents the proportion of explained to unexplained variance (Field 2009). For individual sampling times, we used factorial ANOVAs to analyze the effects of DRI and disturbance type on biomass. All analyses used SPSS version 22 (IBM Corp., Armonk, New York, USA).

\section{Non-structural carbohydrates (NSC) estimations and analysis}

We collected belowground plant parts to analyze NSC in xylem within our plots a few months after treatments (in 2010) and one year after treatments (in 2011). At both times, we used hand tools to carefully excavate storage organs (roots or rhizomes). However, we collected different numbers of samples each time due to logistical constraints. In 2010, we collected a single individual of each of six species from within each plot. In 2011, we collected five samples from four of the most abundant species in our plots (Lyonia fruticosa, L. lucida, Quercus geminata, Q. inopina) from within each plot. We collected samples outside the $1 \mathrm{~m}$ belt transect used for vegetation measurements.

Samples were immediately trimmed and the extracted xylem oven-dried at $60{ }^{\circ} \mathrm{C}$ for $72 \mathrm{~h}$. Dry material was finely ground using a Retsch mill (Retsch MM 400, Düsseldorf, Germany). The soluble and non-soluble fractions of NSC were extracted using the perchloric acid-anthrone method (Morris 1948), on $20 \mathrm{mg}$ of dried and powdered wood (see Olano et al. 2006 for details on the technique). This procedure distinguishes soluble and non-soluble fractions of NSC. Soluble sugars (SS) include mono- and disaccharides such as glucose, fructose, and sucrose. Non-soluble sugars (NSS) include polysaccharides such as starch and fructans. SS and NSS were expressed as the percent by weight of dry mass. Total NSC was estimated as the sum of SS and NSS.

Because not all species were sampled in all years, we analyzed soluble and insoluble fractions of NSC in 2010 and 2011 separately in relation to species, disturbance type, and DRI using general linear models (insoluble fraction was $\ln$ transformed). Effects of 2010 NSC levels on biomass at six months and effects of 2011 NSC levels on biomass at one year were analyzed with linear regressions.

\section{Soil nutrient measurements and analysis}

On 26 April 2011 and 16 April 2012, approximately one and two years after the final treatment application, respectively, we collected and bulked three soil cores (5 cm diameter; $6 \mathrm{~cm}$ depth) from each plot to obtain one sample per plot. Immediately after collection, soils were passed through a $2 \mathrm{~mm}$ sieve to remove large roots and belowground stems. In 2011, sub-samples of soil were weighed for measurement of gravimetric soil moisture, soil organic matter, soil $\mathrm{pH}$, and determination of extractable ammonium $\left(\mathrm{NH}_{4}{ }^{+}\right)$, nitrate $\left(\mathrm{NO}_{3}{ }^{-}\right)$, and phosphate $\left(\mathrm{PO}_{4}{ }^{3-}\right)$. In 2012 , subsamples of soil were weighed for measurement of gravimetric soil moisture and soil organic matter. The inferences we can draw from soil data were constrained by sampling limitations because we did not measure soil properties pre disturbance. However, we expect that soil properties were similar among plots, at least within a disturbance type, since they were all in the same burn unit and had experienced the same management history. 
Gravimetric soil moisture was determined on soils dried at $105^{\circ} \mathrm{C}$ for 48 hours. Soil organic matter was determined using the loss on ignition method (Nelson and Sommers 1996); soils were incubated in a muffle furnace at $400{ }^{\circ} \mathrm{C}$ for 16 hours. Soil $\mathrm{pH}$ was measured on a 1:1 ratio of airdried soil and de-ionized water (Thomas 1996) with an electronic $\mathrm{pH}$ meter (Thermo Orion 320A, Orion Research, Inc., Boston, Massachusetts, USA). To measure inorganic nitrogen $(\mathrm{N}), 50 \mathrm{~mL}$ of $2 \mathrm{M}$ potassium chloride $(\mathrm{KCl})$ was added to $10 \mathrm{~g}$ of field-moist soil, shaken for 30 $\mathrm{s}$, and allowed to stand overnight. We filtered solutions through Fisherbrand Q2 filter paper pre-leached with $2 \mathrm{M}$ $\mathrm{KCl}$. Extracts were stored in the refrigerator for one day then analyzed colorimetrically on a spectrophotometer microplate reader ( $\mu$ Quant Microplate Spectrophotometer, Bio-Tek Instruments, Inc., Winooski, Vermont, USA) at the MacArthur AgroEcology Research Center (MAERC), Lake Placid, Florida, USA. Concentrations of $\mathrm{NH}_{4}{ }^{+}$were determined using the trisodium citrate, salicylatenitroprusside, hypochlorite method (Sims et al. 1995; Mulvaney 1996), and concentrations of $\mathrm{NO}_{3}{ }^{-}$were determined using the vanadium, sulfanilamide, NEDD method (Miranda et al. 2001). To measure extractable phosphorus (P), $30 \mathrm{~mL}$ of $0.05 \mathrm{M}$ hydrochloric acid $(\mathrm{HCl})$ and 0.0125 $\mathrm{M}$ hydrogen sulfate $\left(\mathrm{H}_{2} \mathrm{SO}_{4}\right)$ were added to $15 \mathrm{~g}$ of fieldmoist soil, shaken for $5 \mathrm{~min}$, and then immediately filtered through Fisherbrand Q2 filter paper. Concentrations of phosphate $\left(\mathrm{PO}_{4}{ }^{3-}\right)$ were determined immediately after filtration on a spectrophotometer microplate reader at MAERC using the malachite green method (D'Angelo et al. 2001).

Soil variables were analyzed using a full factorial ANOVA with disturbance type (fire versus mowing) and DRI (annual, biennial, triennial, once in six years) as fixed factors. We analyzed total inorganic $\mathrm{N}$ as the sum of ammonium and nitrate; concentrations of $\mathrm{NO}_{3}{ }^{-}$ were zero in all but one plot. One plot (burned once in six years) had a $\mathrm{NH}_{4}{ }^{+}$concentration over 3.5 times higher than the plot with the next highest $\mathrm{NH}_{4}{ }^{+}$concentration; we suspect that $\mathrm{NH}_{4}{ }^{+}$was high for a reason other than the treatment, so data from this plot were not included in analyses for 2011. We used multiple linear regressions to analyze the effects of 2011 soil variables on biomass in 2011 (one year post treatment) and 2012 (two years post treatment). We used Pearson's r to summarize bivariate relationships between soil variables and biomass (Field 2009). Most soil variables were $\ln$ transformed for analysis.

\section{Results}

Fire weather and temperatures

All burns took place in the late morning and early afternoon. Keetch-Byram Drought indices (Keetch and Byram 1968) ranged from 257 to 705 , indicating little drought to droughty conditions at the time of fire (Table 2). Wind speeds peaked at 8 to $19 \mathrm{~km} \mathrm{hr}^{-1}$ at ground level. Minimum relative humidity varied from 30 to $50 \%$ among the six burn years, and maximum air temperatures were between 23 and $29{ }^{\circ} \mathrm{C}$ (Table 2).

Fire temperatures were generally hot. One-minute mean fire temperatures varied two-fold (from 263 to $531{ }^{\circ} \mathrm{C}$ ) among burn days, while absolute maximum temperatures varied from 414 to $698{ }^{\circ} \mathrm{C}$ among burn days (Table 2). Residence times were often short ( $<5 \mathrm{~min})$, but variable among burn days, with means ranging from 5 to $23 \mathrm{~min}$. Estimated flame lengths varied from 1 to $6 \mathrm{~m}$.

\section{Vegetation responses}

Aboveground biomass of individual plants was strongly influenced by time, species, and DRI, and moderately by disturbance type, with a weak interaction between DRI and disturbance type (Table 3). Frequent disturbance resulted in lower biomass throughout the four years post disturbance, with effects most pronounced in the early stages of recovery (Fig. 2). The strength of the DRI effect on biomass decreased over time $\left(F_{3,163}=8.79, P<0.001\right.$; $F_{3,174}=5.06, P=0.002 ; F_{3,157}=3.73, P=0.013$; and $F_{3,166}=2.02, P=0.113$ for $6 \mathrm{mo}, 1 \mathrm{yr}, 2 \mathrm{yr}$, and $4 \mathrm{yr}$ post treatment, respectively, in separate ANOVAs). Plants in the mown area had higher biomass than plants in the burned area before the disturbance and at each sampling time afterwards, although the recovery patterns were very similar between fire and mowing (Fig. 3). The five genera differed in their biomass recovery (Fig. 4). The two palmetto species recovered their biomass faster than the Lyonia, Quercus, and Vaccinium species (Fig. 4). No species recovered their full biomass after four years.

Table 3 Repeated measures ANOVA results for In (biomass) as a function of time (repeated factor), disturbance frequency (DRI), disturbance type (Type), species, and their interactions. Multivariate tests are shown since the data violated sphericity. We used Roy's largest root for data collected at Archbold Biological Station, Venus, Florida, USA, from 2005 to 2014, as it is the most powerful test in many circumstances (Field 2009). Similar results accrue with tests of within-subject effects in repeated measures ANOVA when corrected for violation of sphericity using Greenhouse-Geisser or Huynh-Feldt corrections

\begin{tabular}{|c|c|c|c|c|c|}
\hline Effect & Roy's largest root & $F$ & df & Error df & $P$ \\
\hline Time & 5.277 & 193.91 & 4 & 147 & $<0.001$ \\
\hline Time * Type & 0.070 & 2.56 & 4 & 147 & 0.041 \\
\hline Time * DRI & 0.139 & 5.19 & 4 & 149 & 0.001 \\
\hline Time * Species & 1.277 & 27.36 & 7 & 150 & $<0.001$ \\
\hline Time * Type * DRI & 0.110 & 4.105 & 4 & 149 & 0.003 \\
\hline Time * Type * Species & 0.156 & 3.339 & 7 & 150 & 0.002 \\
\hline Time * DRI * Species & 0.255 & 1.821 & 21 & 150 & 0.021 \\
\hline Four-way interaction & 0.199 & 1.425 & 21 & 150 & 0.115 \\
\hline
\end{tabular}



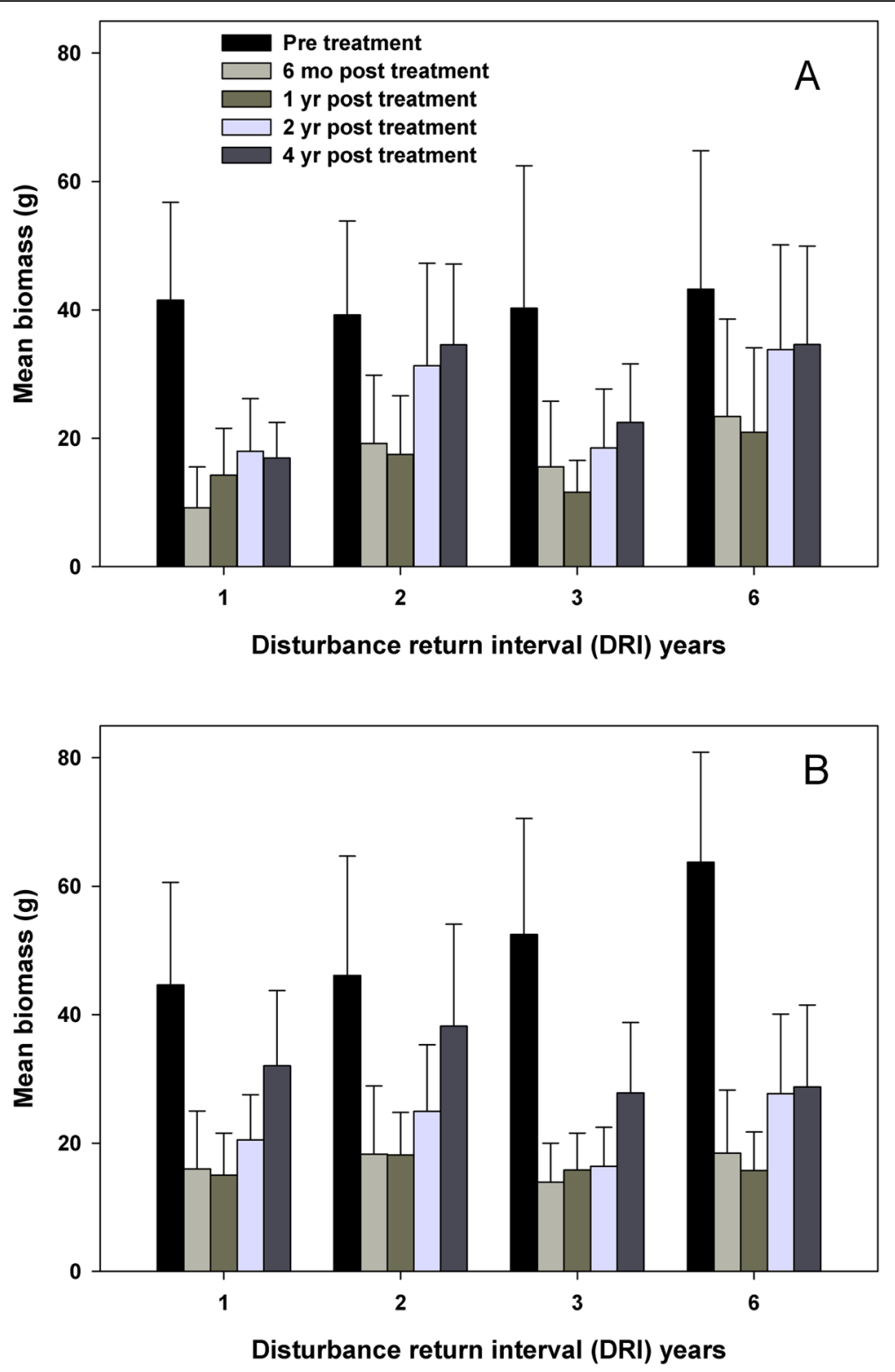

Fig. 2 Mean shrub biomass in (A) burned plots and (B) in mown plots pre treatment and 6 mo, 1 yr, 2 yr, and 4 yr post treatment for each disturbance return interval: annual, DRI $=1$; biennial, $\mathrm{DRI}=2$; once every three years, $\mathrm{DRI}=3$; once in six years, DRI $=6$. The whisker is the $95 \%$ $\mathrm{Cl}$. For burned and mown plots, $n=23$ to 30 and 25 to 29 shrubs for each DRI, respectively. Biomass data are back-transformed. Data collected at Archbold Biological Station, Venus, Florida, USA, from 1994 to 2014. See Table 3 for statistical analysis

When analyzed at the species level, disturbance type and DRI did not significantly affect biomass change over time of most species. However, biomass recovery of $Q$. geminata $\left(F_{9,66}=2.18, P=0.034\right)$ and $Q$. inopina $\left(F_{10,81}=1.98, P=0.046\right)$ was suppressed by frequent disturbance. For Serenoa repens, mowing caused greater biomass decreases and slower recovery than burning $\left(F_{3,227}=3.30, P=0.023\right)$.

Plant height varied significantly among species and with DRI, but not with disturbance type (Table 4). Similar to biomass, plant heights were also negatively affected by frequent fire, with the effect diminishing over time. Individual species also showed very similar effects of DRI and disturbance type on height as on biomass.

Stem numbers were significantly affected by DRI, disturbance type, and species. Stem number increased after disturbances; the increase was lowest in the frequently disturbed treatment (Fig. 5). Mowing increased stem numbers more than burning (Fig. 6). Stem numbers declined over the four years after the last disturbance. Species differed in their stem dynamics, with Lyonia and Quercus species tending to have more stems after disturbance relative to the other species. 


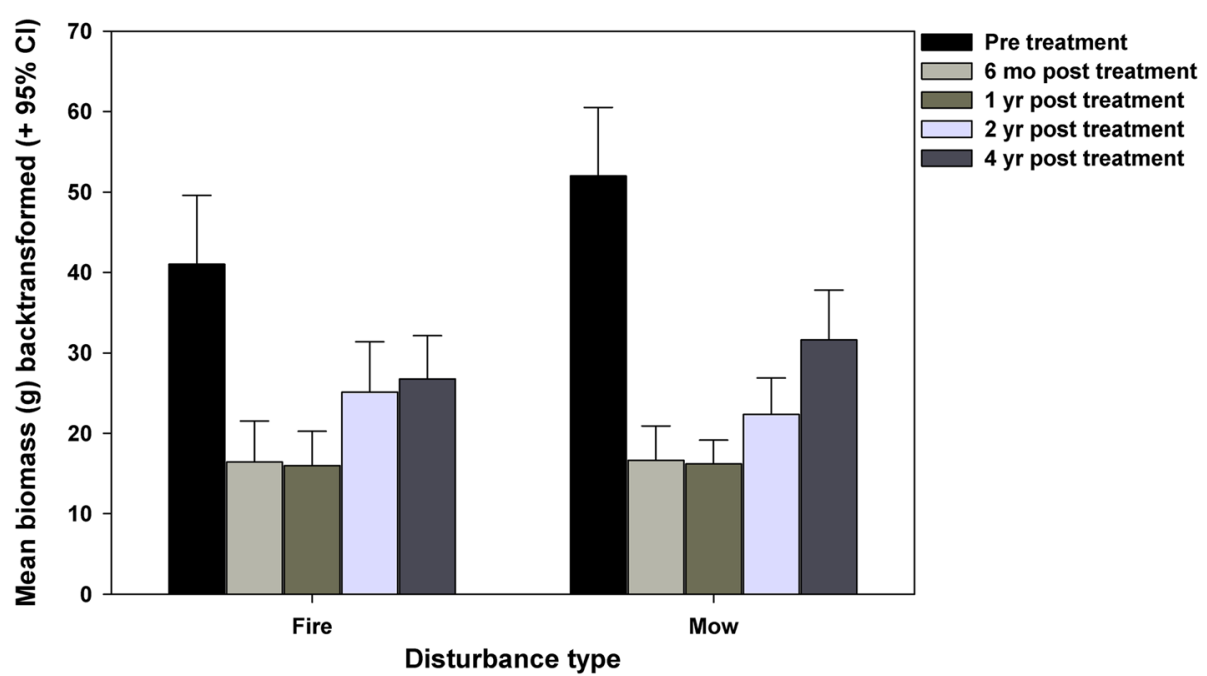

Fig. 3 Mean biomass pre-treatment and $6 \mathrm{mo}, 1 \mathrm{yr}, 2 \mathrm{yr}$, and $4 \mathrm{yr}$ post treatment (across all disturbance return intervals) for both disturbance types, for data collected at Archbold Biological Station, Venus, Florida, USA, from 1994 to 2014. The whisker is the 95\% Cl. Biomass data are backtransformed. See Table 3 for statistical analysis. Number of species within plots $=214$

\section{Non-structural carbohydrates (NSC)}

Most non-structural carbohydrates were in soluble (versus insoluble) fractions across species and sampling times (Table 5). Species patterns over time (right after treatments, one year after treatments) were not consistent; both gains and losses of both types of carbohydrates occurred (Table 5). Total soluble NSC in both 2010 and 2011 were strongly affected by species
$\left(F_{4,54}=4.71, P<0.001\right.$ in $2010 ; F_{3,87}=5.995, P=0.001$ in 2011), but no effects of DRI, disturbance type, or interactions were significant. Total insoluble NSC in 2010 was significantly related to species $\left(F_{4,54}=30.1, P<0.001\right)$ and disturbance type $\left(F_{1,54}=4.7, P=0.034\right)$, but not DRI or interactions. In 2011, total insoluble NSC was related to species $\left(F_{3,87}=80.2, P<0.001\right)$, but not DRI, disturbance type, or interactions. In 2010, total

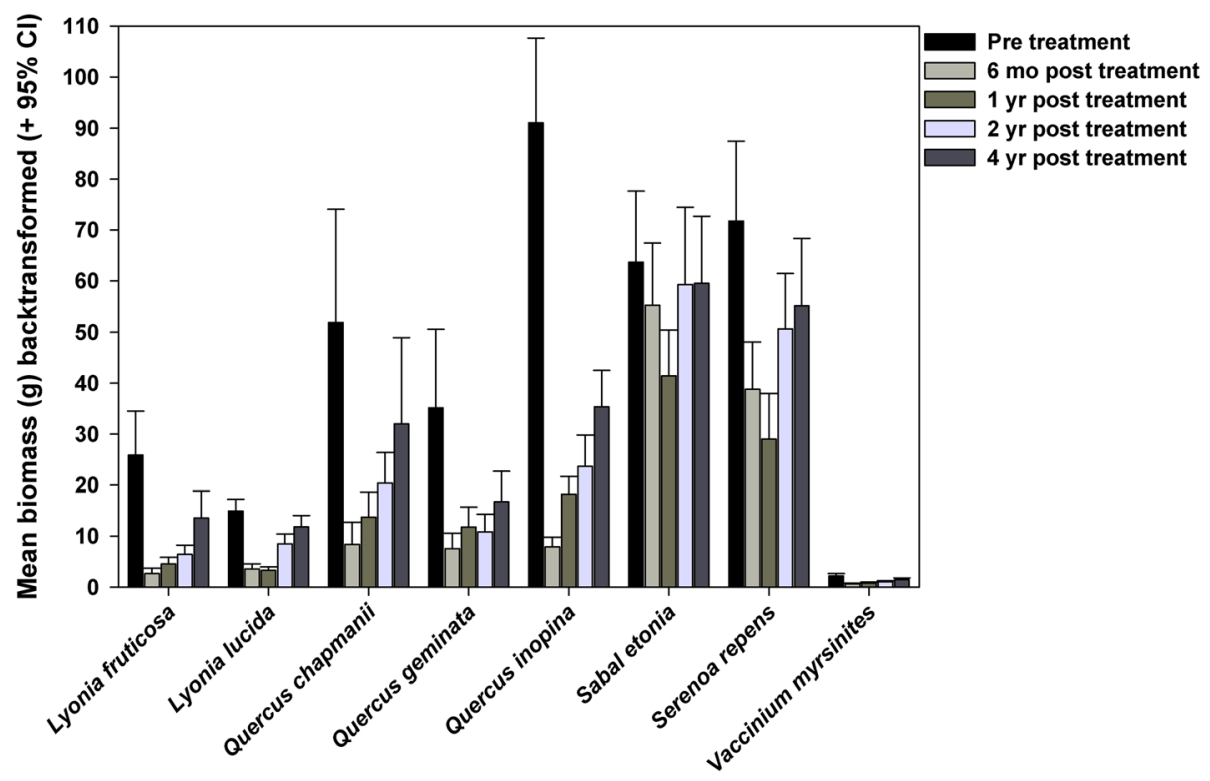

Fig. 4 Mean biomass of each species pre treatment and $6 \mathrm{mo}, 1 \mathrm{yr}, 2 \mathrm{yr}$, and $4 \mathrm{yr}$ post treatment, for both mowing and burning and all DRI treatments combined, at Archbold Biological Station, Venus, Florida, USA, from 1994 to 2014. The whisker is the 95\% Cl. Biomass data are back-transformed. See Table 3 for statistical analysis. Sample sizes for each species by year: Lyonia fruticose, $n=25$ to $29 ;$ L. lucida $n=29$; Quercus chapmanii, $n=20$ to 29 ; Q. geminata, $n=30$; $Q$. inopina, $n=32$; Sabal etonia, $n=28$ to 30; Serenoa repens, $n=32$; Vaccinium myrsinites, $n=25$ to 31 
Table 4 Repeated measures ANOVA results for In (height) as a function of time (repeated factor), disturbance frequency (DRI), disturbance type (Type), species, and their interactions, for data collected at Archbold Biological Station, Venus, Florida, USA, from 2005 to 2014. See Table 3 for additional information on statistical approach

\begin{tabular}{llrrrr}
\hline Effect & Roy's largest root & \multicolumn{1}{c}{$F$} & df & Error df & $P$ \\
\hline Time & 6.197 & 227.72 & 4 & 147 & $<0.001$ \\
Time * Type & 0.047 & 1.73 & 4 & 147 & 0.147 \\
Time * DRI & 0.143 & 5.32 & 4 & 149 & $<0.001$ \\
Time * Species & 1.832 & 39.26 & 7 & 150 & 0.001 \\
Time * Type * DRI & 0.142 & 5.30 & 4 & 149 & 0.001 \\
Time * Type * Species & 0.183 & 3.91 & 7 & 150 & 0.001 \\
Time * DRI * Species & 0.259 & 1.849 & 21 & 150 & 0.018 \\
Four way interaction & 0.244 & 1.746 & 21 & 150 & 0.030 \\
\hline
\end{tabular}

insoluble NSC was higher in burned areas than in mown areas.

Aboveground biomass was related to carbohydrate levels in multiple regressions with both fractions. Biomass at six months was positively related to the insoluble NSC fraction (slope $=0.763, t=7.837, P<0.001$ ), but not to the soluble fraction (slope $=-0.048, t=1.534, P=0.129$ ). On its own, NSC was positively correlated with 6-month biomass, explaining nearly half of its variance (Fig. 7).

After one year (in 2011), biomass was negatively related to the insoluble fraction (slope $=-0.233, t=-6.143, P<0.001$ ) and positively correlated with the soluble fraction (slope $=0.062, t=1.991, P=0.049$ ). By itself, the 2011 insoluble fraction explained over $30 \%$ of the variance in aboveground biomass $(\mathrm{r}=-0.563, P<0.001)$.
Soil

Gravimetric soil moisture and percent soil organic matter (SOM) were significantly higher in mowed plots than in burned plots one and two years after disturbance (Table 6). Conversely, soil $\mathrm{pH}$ was significantly higher in burned plots than in mowed plots. DRI had no effect on soil moisture, $\mathrm{SOM}$, or $\mathrm{pH}$ (Table 6). Phosphate and inorganic $\mathrm{N}$ concentrations were not affected by disturbance type or DRI. Biomass one year (when complete soil data were collected) and two years post treatment were unrelated to any of the five soil variables in multiple linear regressions (Table 7).

\section{Discussion}

The main finding of this field experiment was that very frequent disturbances suppressed resprouting biomass and growth, as hypothesized. Frequent, especially annual, disturbances had the largest effects, particularly shortly (six months to one year) after disturbance. Suppression of resprouting vigor by frequent disturbances has been documented in other ecosystems. For example, frequent clipping reduced shrub resprouting vigor in Mediterranean shrublands (Paula and Ojeda 2006). In Australian shrublands, more frequent fire led to increased mortality, but did not decrease growth in resprouting shrubs (Enright et al. 2011).

Disturbance type (mowing versus burning) had a limited effect on resprouting dynamics of scrubby flatwoods shrub species. Similarly, many studies have found little difference in resprouting or woody cover after burning versus mowing or cutting or clipping (e.g., Hmielowski et al. 2014; Peterson and Drewa 2014; Michielsen et al. 2017). In

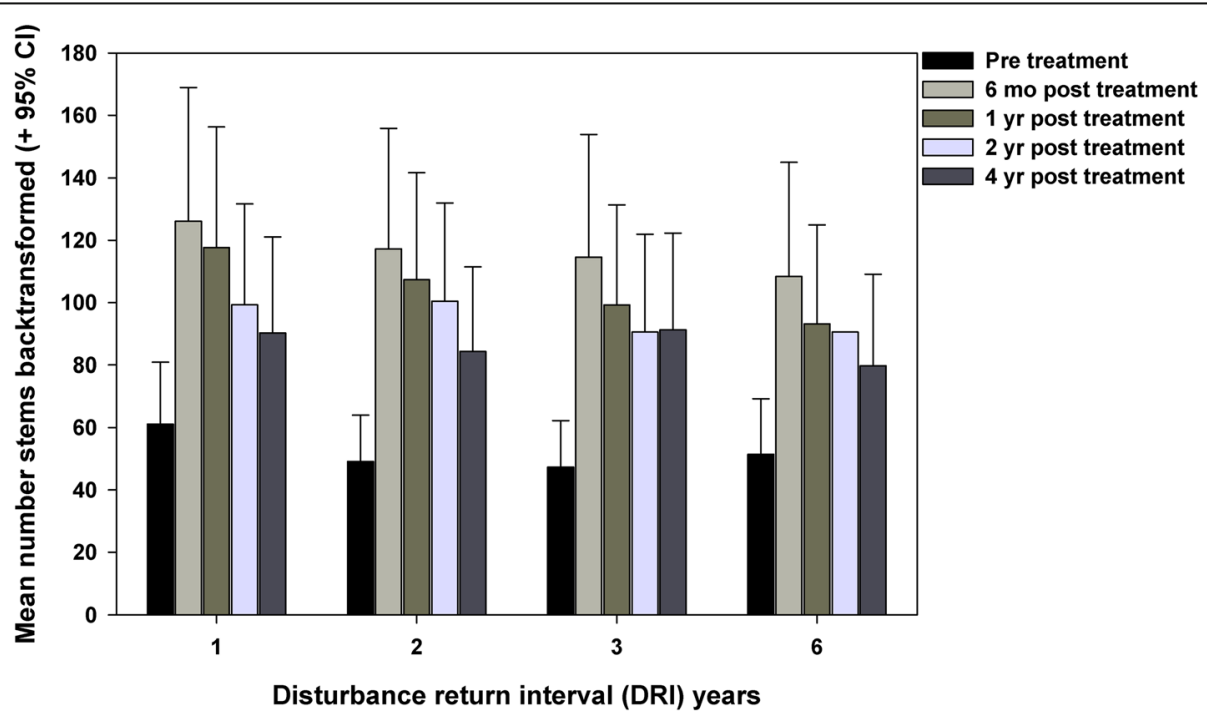

Fig. 5 Mean number of stems pre treatment and four times post treatment ( $6 \mathrm{mo}, 1 \mathrm{yr}, 2 \mathrm{yr}, 4 \mathrm{yr}$ ) for each disturbance return interval: annual, DRI = 1; biennial, DRI = 2; once every three years, DRI = 3; once in six years, DRI =6. Both burned and mown plots are combined. The whisker is the $95 \% \mathrm{Cl}$. Number of stems is back-transformed. See Table 4 for statistical analysis. Number of species per plot $=219$ to 230 by year. Data collected at Archbold Biological Station, Venus, Florida, USA, from 1994 to 2014 


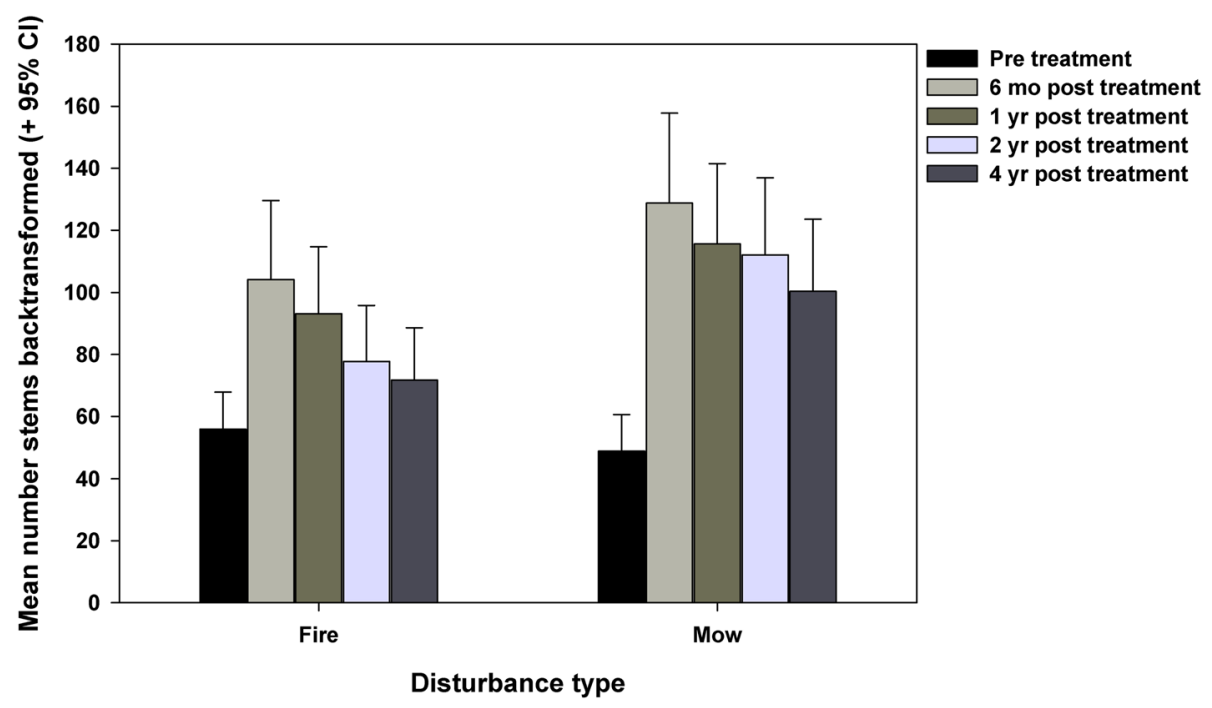

Fig. 6 Mean number of stems pre treatment and four times post treatment ( 6 mo, 1 yr, 2 yr, 4 yr) for both disturbance types, combined across all DRI treatments. The whisker is the $95 \% \mathrm{Cl}$. Number of stem data are back-transformed. See Table 4 for statistical analysis. Number of species per plot $=214$. Data collected at Archbold Biological Station, Venus, Florida, USA, 1994 to 2014

contrast, some studies have found that burning results in higher mortality and lower post-disturbance growth than cutting (Peguero and Espelta 2011; Noble and Diggle 2014). High fire temperatures may increase mortality (compared to clipping) for some resprouting shrubs (Lloret and Lopez-Soria 1993).

Mowing increased stem numbers more than burning. This contradicted our hypothesis that plants would grow faster after fire than after mowing due to nutrient fertilization from ash. Instead, it suggests that negative effects of fire on bud banks may outweigh positive effects of fire on nutrient availability. Increases in the number of stems in resprouting species after disturbances such as fire

Table 5 Mean (standard error, among plots) percent by weight of dry weight of soluble and insoluble non-structural carbohydrates shortly after treatments (April 2010) and one year after treatments (April 2011), by species, for data collected at Archbold Biological Station, Venus, Florida, USA, from 2005 to 2014. Total $n=119$; $n$ for each species-date combination ranged from 11 to 32 . Standard error is listed in parentheses

\begin{tabular}{|c|c|c|c|c|}
\hline \multirow[b]{3}{*}{ Species } & \multicolumn{4}{|c|}{ Mean non-structural carbohydrates (\%) } \\
\hline & \multicolumn{2}{|l|}{ Soluble } & \multicolumn{2}{|l|}{ Insoluble } \\
\hline & 2010 & 2011 & 2010 & 2011 \\
\hline Lyonia fruticosa & $11.04(0.46)$ & $11.26(0.40)$ & $0.59(0.14)$ & $3.83(0.34)$ \\
\hline Lyonia lucida & & $9.91(0.23)$ & & $4.64(0.31)$ \\
\hline Quercus geminata & $7.23(1.08)$ & $11.31(0.40)$ & $0.46(0.06)$ & $1.48(0.11)$ \\
\hline Quercus inopina & $10.14(0.46)$ & $12.47(0.52)$ & $0.95(0.11)$ & $1.20(0.09)$ \\
\hline Serenoa repens & $8.85(1.17)$ & & $5.71(0.85)$ & \\
\hline Vaccinium myrsinites & $11.90(0.45)$ & & $0.58(0.12)$ & \\
\hline
\end{tabular}

are commonly found (e.g., Kauffman and Martin 1990; Heisler et al. 2004). Mowing, as compared to burning, caused greater initial increases in numbers of stems, a result consistent with a shadehouse experiment on Quercus nigra L. in pine savanna (Hmielowski et al. 2014). Less vigorous responses in stem numbers after burning could represent loss of buds due to the heat of the fire (Clarke et al. 2013). Mowing, as compared to burning, did not affect patterns of resprouting biomass recovery for most species. However, Serenoa repens recovery was slower with mowing than with burning, suggesting a mechanism that land managers could use to alter abundances of this often dominant species. Shrubs in the mown area had greater biomass than shrubs in the burned area, both before and after treatments. The mown area was at a slightly lower elevation (means differ by $0.12 \mathrm{~m}$ based on LiDAR stored at Archbold Biological Station), which could increase availability of both water and nitrogen (McKinley et al. 2009). In fact, the mown site had greater soil moisture and organic matter than the burned area one year after the last disturbance, which could have contributed to the higher biomass in mowed plots and greater increases in stem number after disturbance. Mown areas also may have had higher soil moisture after treatments due to plant litter on the soil surface retaining water and reducing evaporation.

Species differed in their growth after the disturbance treatments, agreeing with results from Maguire and Menges (2011) showing differential responses of species post fire. In particular, both palmetto species (Serenoa repens and Sabal etonia) recovered height and biomass faster than the other shrubs. This rapid post-disturbance response is consistent with strong post-fire growth and 


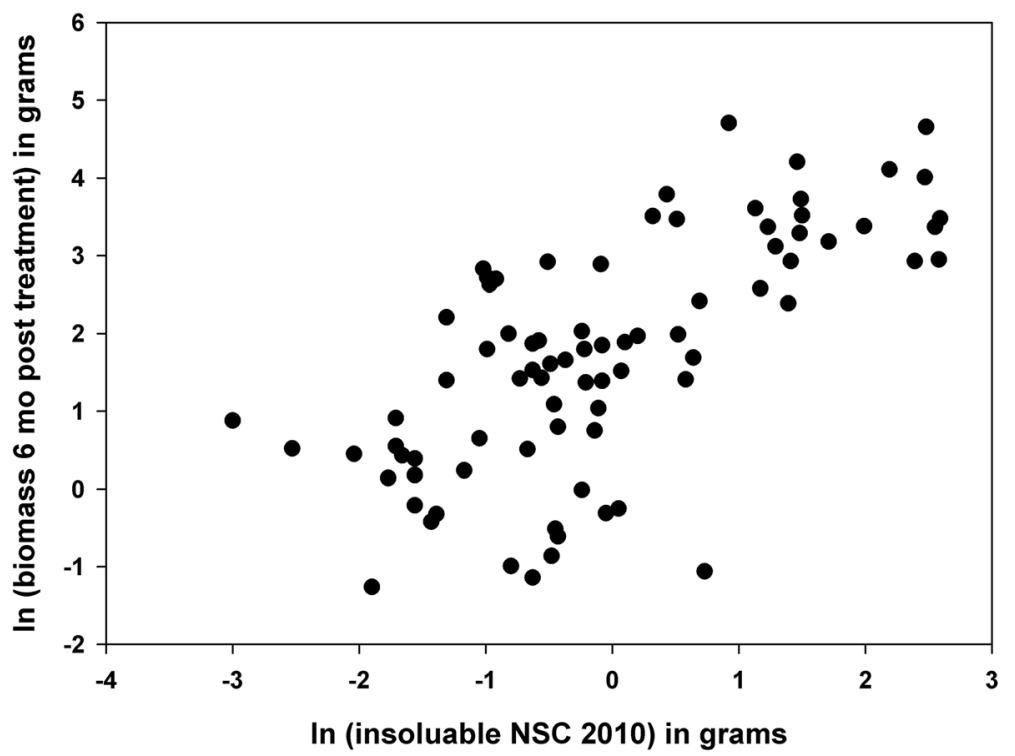

Fig. 7 Correlation between insoluble non-structural carbohydrates (NSC) after the last treatment (In transformed) and shrub biomass six months post treatment (In transformed). Each point represents biomass and NSC for an individual species and plot. Pearson's $r=0.680, P<0.001$.

Number of samples $=81$. Data collected at Archbold Biological Station, Venus, Florida, USA, from 1994 to 2014

Table 6 Effects of disturbance type (Type), disturbance return internal (DRI), and their interaction on soil properties, for data collected at Archbold Biological Station, Venus, Florida, USA, from 2005 to 2014. Results of full factorial ANOVAs with disturbance variables as fixed factors. Also shown are mean values for soil variables across all burned or mown plots

\begin{tabular}{|c|c|c|c|c|c|c|}
\hline \multirow[b]{2}{*}{ Soil variable } & \multirow[b]{2}{*}{ Factor } & \multirow[b]{2}{*}{$F$} & \multirow[b]{2}{*}{ df } & \multirow[b]{2}{*}{ P } & \multicolumn{2}{|c|}{ Mean value } \\
\hline & & & & & Burn & Mow \\
\hline \multirow[t]{3}{*}{ Gravimetric soil moisture In $(\% ; 2011)$} & Type & 16.96 & 1 & $<0.001$ & 0.61 & 1.13 \\
\hline & DRI & 0.33 & 3 & 0.807 & & \\
\hline & Type * DRI & 2.04 & 3 & 0.136 & & \\
\hline \multirow[t]{3}{*}{ Gravimetric soil moisture In(\%; 2012) } & Type & 14.96 & 1 & 0.001 & 0.50 & 0.77 \\
\hline & DRI & 1.35 & 3 & 0.283 & & \\
\hline & Type * DRI & 2.47 & 3 & 0.087 & & \\
\hline \multirow[t]{3}{*}{ Organic matter (\%) (2011) } & Type & 4.28 & 1 & 0.050 & 1.99 & 2.95 \\
\hline & DRI & 0.51 & 3 & 0.681 & & \\
\hline & Type * DRI & 1.54 & 3 & 0.231 & & \\
\hline \multirow[t]{3}{*}{ Organic matter (\%) (2012) } & Type & 6.66 & 1 & 0.017 & 2.36 & 3.12 \\
\hline & DRI & 0.83 & 3 & 0.490 & & \\
\hline & Type * DRI & 1.32 & 3 & 0.293 & & \\
\hline \multirow[t]{3}{*}{ pH (2011) } & Type & 12.15 & 1 & 0.002 & 5.05 & 4.55 \\
\hline & DRI & 0.54 & 3 & 0.543 & & \\
\hline & Type * DRI & 1.52 & 3 & 0.235 & & \\
\hline \multirow[t]{3}{*}{ Total inorganic N $\ln \left(\mu \mathrm{g} \mathrm{g}{ }^{-1}\right.$ soil; 2011) } & Type & 0.81 & 1 & 0.377 & 1.32 & 1.59 \\
\hline & DRI & 1.40 & 3 & 0.268 & & \\
\hline & Type * DRI & 2.79 & 3 & 0.063 & & \\
\hline \multirow[t]{3}{*}{$\mathrm{PO}_{4}^{3-} \ln \left(\mu \mathrm{g} \mathrm{g}{ }^{-1}\right.$ soil; 2011) } & Type & 1.85 & 1 & 0.187 & 1.34 & 0.70 \\
\hline & DRI & 0.56 & 3 & 0.644 & & \\
\hline & Type * DRI & 1.90 & 3 & 0.159 & & \\
\hline
\end{tabular}


Table 7 Effects of 2011 soil variables on biomass (In) one and two years after treatments, for data collected at Archbold Biological Station, Venus, Florida, USA, from 2005 to 2014. $n=231$ and $n=214$ for one and two years, respectively. B = slope, SE $=$ standard error, Beta $=$ standardized coefficient, $t=$ student's $t$ test

\begin{tabular}{|c|c|c|c|c|c|c|}
\hline Time & Variable & B & SE & Beta & t & $P$ \\
\hline \multirow[t]{6}{*}{ One year } & Constant & 1.948 & 2.272 & & 0.857 & 0.392 \\
\hline & Soil moisture (In) & 0.272 & 0.334 & 0.120 & 0.812 & 0.418 \\
\hline & $\mathrm{pH}$ & 0.087 & 0.464 & 0.029 & 0.187 & 0.852 \\
\hline & Organic matter (\%) & -0.128 & 0.171 & -0.116 & -0.748 & 0.455 \\
\hline & Total inorganic N (In) & 0.395 & 0.297 & 0.162 & 1.329 & 0.185 \\
\hline & $\mathrm{PO}_{4}^{3-}(\mathrm{In})$ & -0.070 & 0.227 & -0.032 & -0.307 & 0.759 \\
\hline \multirow[t]{6}{*}{ Two years } & Constant & 0.791 & 2.393 & & 0.330 & 0.741 \\
\hline & Soil moisture (In) & 0.330 & 0.349 & 0.145 & 0.946 & 0.345 \\
\hline & $\mathrm{pH}$ & 0.414 & 0.485 & 0.135 & 0.853 & 0.395 \\
\hline & Organic matter (\%) & -0.146 & 0.187 & -0.130 & -0.780 & 0.436 \\
\hline & Total inorganic N (In) & 0.454 & 0.316 & 0.188 & 1.437 & 0.152 \\
\hline & $\mathrm{PO}_{4}^{3-}(\mathrm{In})$ & -0.165 & 0.236 & -0.077 & -0.699 & 0.485 \\
\hline
\end{tabular}

flowering in these species at ABS (Abrahamson 1999) and the recovery of $S$. repens cover within a year after fire in oak-palmetto scrub in coastal Florida (Schmalzer and Hinkle 1992). Fast recovery of palmettos may be due to their deep roots (Saha et al. 2010), high carbohydrate storage levels (Hough 1968), and the fact that they do not invest in secondary growth. Serenoa repens was also the only species in our study that was affected by disturbance type, with lower biomass recovery in the mown treatment than in the burned treatment. This is consistent with reductions in S. repens cover following mechanical disturbances, which can damage its aboveground rhizomes (Kreye et al. 2016). The rhizomes and roots of other species are belowground, thus protected from mowing.

Our results support the existence of a robust but complex link between stored NSC and post-disturbance recovery. Non-structural carbohydrates fuel survival and growth during resprouting (Canadell and Lopez-Soria 1998; Wigley et al. 2009) until carbon balance becomes positive. Higher NSC levels promote more efficient responses to disturbances such as fire or drought (Tolsma et al. 2010; de Moraes et al. 2016; but see Poorter et al. 2010). NSC levels decreased five months after fire in $S$. repens (Kalmbacher et al. 1983), but resource reserves in other species can recover as soon as one year after fire when the full canopy is rebuilt (Schutz et al. 2009). Although our NSC data were limited by logistical constraints, the existence of a strong positive correlation between insoluble NSC and biomass six months after treatment in our study indicates that having high insoluble NSC is a good predictor of future growth, as found in several tree species (DeSoto et al. 2016; von Arx et al. 2017). A positive correlation between soluble sugars and growth one year after perturbation might indicate that faster growing plants are mobilizing more carbohydrates. Although we expected that the link between insoluble NSC levels would not last long after perturbation, the existence of a negative correlation between insoluble NSC and growth was an unexpected result. One explanation is that more efficient remobilization of insoluble NSC resources could lead to higher NSC depletion (and higher soluble sugars concentration) in fast growing plants; however, this hypothesis needs more evidence to be supported.

The hypothesis that soil nutrient availability would affect the resprouting response of shrubs was not supported. Soil properties were not affected by DRI. However, the significant interaction effect on inorganic $\mathrm{N}$, due to higher $\mathrm{N}$ concentrations in the plots burned once in six years, partially aligns with another study that found that more frequent fire reduces inorganic nutrient availability (Hernandez and Hobbie 2008). Mown areas had higher soil moisture and organic matter than burned areas, but there was no effect of disturbance type on availability of inorganic $\mathrm{N}$ and $\mathrm{P}$. A greater proportion of available soil $\mathrm{N}$ in scrubby flatwoods is in organic form than is in inorganic form (Schafer and Mack 2013), so total $\mathrm{N}$ availability may be a better measure of plantavailable $\mathrm{N}$ than inorganic $\mathrm{N}$ availability. Most importantly, soil properties did not affect biomass responses (one or two years after treatments). Since we did not measure nutrient availability immediately after disturbance, when nutrient pulses occur (Schafer and Mack 2010), we may have missed short-term soil nutrient effects on plant responses.

This experiment provides evidence that frequent fires reduce the growth of resprouting shrubs in scrubby flatwoods. However, there are several limitations of this experiment. First, the study could have underestimated the role of very frequent disturbances 
over longer time spans than 10 years. Second, more complete temporal sampling is necessary to better understand the roles of carbohydrates and soil nutrients in resprouting responses. Other caveats include potentially altered fire intensities and nutrient availability due to the necessary addition of fuels to complete the frequent burns; potentially reduced fire intensities from the use of narrow plots; variable conditions among burns that might affect plant responses; and the timing of burns in March and April, slightly before the peak May fire season (Platt et al. 2015), which was necessary to obtain burn authorizations from the Florida Forest Service. Finally, we cannot address the potential differential survival of plants with different levels of DRI or different disturbance types because we did not mark individual plants. However, our observations suggest that there was little mortality, even in frequently disturbed plots.

\section{Conclusions}

Although frequent disturbances suppressed the growth of resprouting shrubs, the effects were small; differences among DRI treatments in mean height were 5 to $9 \mathrm{~cm}$ over the course of the study. We also did not observe any increase in dead stems over time or in the most frequently disturbed treatments, which would have indicated mortality. Mowing and fire produced similar patterns in plant responses, suggesting that nutrient and heat effects of fire were not strong drivers of growth patterns. These results show that scrubby flatwoods shrubs should be resilient to frequent fires.

\section{Management recommendations}

Recommendations for fire return intervals for scrubby flatwoods (8 to 16 years in Menges 2007; 6 to 19 years in Menges et al. 2017) suggest less frequent burning than the fire return intervals used in the experiment. However, land managers may want to burn more frequently in some circumstances to reduce the density of the obligately seeding Pinus clausa (Myers 1985) or to create gaps that are crucial to subordinate plant species (Schmalzer 2003; Menges et al. 2017). In the current study, we did not find any evidence that high fire or mowing frequencies are likely to eliminate dominant scrubby flatwoods plants. We suggest that land managers can use frequent fires (as often as every three years, which may be the maximum possible without fuel additions) to accomplish restoration of Florida scrub.

\section{Acknowledgements}

We appreciate the help of numerous prescribed burners from Archbold Biological Station, The Nature Conservancy, and Florida Fish and Wildlife Conservation Commission, including L. Gonzalez and R. Pickert, who helped with many of the burns. We also thank those who helped with measurements in the field: S. Haller Crate, R. Burnett, J. Peeler, D. Picklum, E. Sass, M. Blaha, J. Jones, M.P. Mugnani, M. Franke, J. Benning, K. Peterson, K.
Carmen, S. Morowski, J. Kupihea, R. King, J. Gehring, C. Ficken, J. Dee, C. Kellman, A. Peschel, L. Peck, G. Schneider, M. Paul, J. Lange, R. Cressey, A. Stathos, C. Bertz, A. David, M. Larson-Liebner, J. Wheeler, D. Horton, S. Koontz, T. Miller, A. Maguire, D. Zaya, J. Navarra, S. Hicks Dean, L. Sullivan, J. Lowell, K. Prengaman, K. Adams, I. Pfingstein, D. White, R. Hewitt, A. Hansgate, K. Stuble, B. Stephens, T. Strazisar, and M. Ellis.

\section{Authors' contributions}

ESM conceived of the study. All authors helped design the study and collect data. ESM analyzed the data with advice of all authors. ESM wrote the manuscript. The authors edited and approved the final manuscript.

\section{Funding}

Funding from the National Science Foundation DEB0812717 was greatly appreciated.

\section{Availability of data and materials}

Data posted online at doi:10.6073/pasta/dafd787651f06e15ca8c775e52d877da

Ethics approval and consent to participate

Not applicable.

\section{Consent for publication}

Not applicable.

Competing interests

The authors declare that they have no competing interests.

\section{Author details}

${ }^{1}$ Archbold Biological Station, 123 Main Drive, Venus, Florida 33960, USA.

2Universidad de Valladolid, Campus Duques de Soria, 42004 Soria, Spain.

${ }^{3}$ Department of Biology, Winthrop University, 701 Oakland Avenue, Rock Hill, South Carolina 29733, USA.

Received: 1 March 2019 Accepted: 19 February 2020

Published online: 16 March 2020

\section{References}

Abrahamson, W.G. 1984. Post-fire recovery of Florida Lake Wales Ridge vegetation. American Journal of Botany 71: 9-21 https://doi.org/10.1002/j. 1537-2197.1984.tb12479.x.

Abrahamson, W.G. 1999. Episodic reproduction in two fire-prone palms, Serenoa repens and Sabal etonia (Palmae). Ecology 80: 100-115 https://doi.org/10. 1890/0012-9658(1999)080[0100:ERITFP]2.0.CO;2.

Abrahamson, W.G., A.F. Johnson, J.N. Layne, and P.A. Peroni. 1984. Vegetation of the Archbold Biological Station, Florida: an example of the southern Lake Wales Ridge. Florida Scientist 47: 209-251.

Ashton, K.G., B.M. Engelhardt, and B.S. Branciforte. 2008. Gopher tortoise (Gopherus polyphemus) abundance and distribution after prescribed fire reintroduction to Florida scrub and sandhill at Archbold Biological Station. Journal of Herpetology 42: 523-529 https://doi.org/10.1670/06-246.1.

Bellingham, P.J., and A.D. Sparrow. 2000. Resprouting as a life history strategy in woody plant communities. Oikos 89: 409-416 https://doi.org/10.1034/j.16000706.2000.890224.x.

Bond, W.J., and J.J. Midgley. 2001. Ecology of sprouting in woody plants: the persistence niche. Trends in Ecology and Evolution 16: 45-51 https://doi.org/ 10.1016/S0169-5347(00)02033-4.

Breininger, D.R., V.L. Larson, B.W. Duncan, R.B. Smith, D.M. Oddy, and M.F. Goodchild. 1995. Landscape patterns of Florida scrub jay habitat use and demographic success. Conservation Biology 9: 1442-1453 https://doi.org/10. 1046/j.1523-1739.1995.09061442.x.

Brenner, J., and D. Wade. 2003. Florida's revised prescribed fire law: protection for responsible burners. In Proceedings of Fire Conference 2000: the first national congress on fire ecology, prevention, and management. Miscellaneous Publication No. 13, ed. K.E.M. Galley, R.C. Klinger, and N.G. Sugihara, 132-136. Tallahassee: Tall Timbers Research Station.

Briggs, J.M., A.K. Knapp, and B.L. Brock. 2002. Expansion of woody plants in tallgrass prairie: a fifteen-year study of fire and fire-grazing interactions. American Midland Naturalist 147: 287-294 https://doi.org/10.1674/00030031 (2002)147[0287:EOWPIT]2.0.CO;2. 
Canadell, J., and L. Lopez-Soria. 1998. Lignotuber reserves support regrowth following clipping of two Mediterranean shrubs. Functional Ecology 12: 31-38 https://doi.org/10.1046/j.1365-2435.1998.00154.x.

Carter, L.J., D. Lewis, L. Crockett, and J. Vega. 1989. Soil survey of Highlands County, Florida. Gainesville, Florida, USA: Soil Conservation Service.

Clarke, P.J., D.M. Bell, and M.J. Lawes. 2015. Testing the shifting persistence niche concept: plant resprouting along gradients of disturbance. American Naturalist 185: 747-755 https://doi.org/10.1086/681160.

Clarke, P.J., M.J. Lawes, J.J. Midgley, B.B. Lamont, F. Ojeda, G.E. Burrows, N.J. Enright, and K.J.E. Knox. 2013. Resprouting as a key functional trait: how buds, protection and resources drive persistence after fire. New Phytologist 197: 19-35 https://doi.org/10.1111/nph.12001.

Cruz, A., B. Perez, and J.M. Moreno. 2003. Plant stored reserves do not drive resprouting of the lignotuberous shrub Erica australis. New Phytologist 157: 251-259 https://doi.org/10.1046/j.1469-8137.2003.00668.x.

D'Angelo, E., J. Crutchfield, and Mm Vandiviere. 2001. Rapid, sensitive, microscale determination of phosphate in water and soil. Journal of Environmental Quality 30: 2206-2209 https://doi.org/10.2134/jeq2001.2206.

Dean, S., E.C. Farrer, and E.S. Menges. 2015. Fire effects on soil biogeochemistry in Florida scrubby flatwoods. American Midland Naturalist 174: 49-64 https:// doi.org/10.1674/0003-0031-174.1.49.

Dee, J.R., and E.S. Menges. 2014. Gap ecology in Florida scrubby flatwoods: effects of time-since-fire, gap size, gap aggregation, and microhabitat on species occurrence and composition. Journal of Vegetation Science 25: 1235-1246 https://doi.org/10.1111/jvs.12170.

de Moraes, M.G., M.A.M. de Carvalho, A.C. Franco, C.J. Pollock, and R.C.L. Figueiredo-Ribeiro. 2016. Fire and drought: soluble carbohydrate storage and survival mechanisms in herbaceous plants from the cerrado. BioScience 66: 107-117 https://doi.org/10.1093/biosci/biv178.

DeSoto, L., J.M. Olano, and V. Rozas. 2016. Secondary growth and carbohydrate storage patterns differ between sexes in Juniperus thurifera. Frontiers in Plant Science 7: 723 https://doi.org/10.3389/fpls.2016.00723.

Enright, N.J., J.B. Fontaine, V.C. Westcott, J.C. Lade, and B.P. Miller. 2011. Fire interval effects on persistence of resprouting species in mediterranean-type shrublands. Plant Ecology 212: 2071-2083 https://doi.org/10.1007/s11258-011-9970-7.

Estill, J., and M. Cruzan. 2001. Phytogeography of rare plant species endemic to the southeastern United States. Castanea 66 (1-2): 3-23.

Ficken, C.D., and J.P. Wright. 2017. Contributions of microbial activity and ash deposition to post-fire nitrogen availability in a pine savanna. Biogeosciences 14: 241-255 https://doi.org/10.5194/bg-14-241-2017.

Field, A. 2009. Discovering statistics using SPSS. 3rd ed. Los Angeles: Sage.

Glitzenstein, J.S., D.R. Streng, R.E. Masters, K.M. Robertson, and S.M. Hermann. 2012. Fire-frequency effects on vegetation in north Florida pinelands: another look at the long-term Stoddard Fire research plots at Tall Timbers Research Station. Forest Ecology and Management 264: 197-209 https://doi. org/10.1016/j.foreco.2011.10.014.

Gower, K., J.B. Fontaine, C. Birnbaum, and N.J. Enright. 2015. Sequential disturbance effects of hailstorm and fire on vegetation in a mediterranean-type ecosystem. Ecosystems 18: 1121-1134 https://doi.org/10.1007/s10021-015-9886-5.

Heisler, J.L., J.M. Briggs, A.K. Knapp, J.M. Blair, and A. Seery. 2004. Direct and indirect effects of fire on shrub density and aboveground productivity in a mesic grassland. Ecology 85: 2245-2257 https://doi. org/10.1890/03-0574.

Hernandez, D.L., and S.E. Hobbie. 2008. Effects of fire frequency on oak litter decomposition and nitrogen dynamics. Oecologia 158: 535-543 https://doi org/10.1007/s00442-008-1162-3.

Hmielowski, T.L., K.M. Robertson, and W.J. Platt. 2014. Influence of season and method of top-kill on resprouting characteristics and biomass of Quercus nigra saplings from a southeastern US pine-grassland ecosystem. Plant Ecology 215: 1221-1231 https://doi.org/10.1007/s11258-014-0380-5.

Hough, W.A. 1968. Carbohydrate reserves of saw-palmetto: seasonal variation and effects of burning. Forest Science 14: 399-405.

Huddle, J.A., and S.G. Pallardy. 1999. Effect of fire on survival and growth of Acer rubrum and Quercus seedlings. Forest Ecology and Management 118: 49-56 https://doi.org/10.1016/S0378-1127(98)00485-X.

Kalmbacher, R.S., K.J. Boote, and F.G. Martin. 1983. Burning and 2, 4, 5-T application on mortality and carbohydrate reserves in saw-palmetto. Journal of Range Management 36: 9-12 https://doi.org/10.2307/3897970.

Kauffman, J.B., and R.E. Martin. 1990. Sprouting shrub response to different seasons and fuel consumption levels of prescribed fire in Sierra Nevada mixed conifer ecosystems. Forest Science 36: 748-764.
Keetch, J.J., and G. Byram. 1968. A drought index for forest fire control. USDA Forest Service Research Paper SE-38. Asheville: USDA Forest Service, Southeastern Forest Experiment Station.

Klimesova, J., T. Herben, and J. Martinkova. 2017. Disturbance is an important factor in the evolution and distribution of root-sprouting species. Evolutionary Ecology 31: 387-399 https://doi.org/10.1007/s10682-016-9881-0.

Knight, T.M., and R.D. Holt. 2005. Fire generates spatial gradients in herbivory: an example from a Florida sandhill ecosystem. Ecology 86: 587-593 https://doi. org/10.1890/04-1069.

Kreye, J.K., J.M. Varner, and L.N. Kobziar. 2016. Mechanical mastication as a fuels treatment in southeastern forests. In Proceedings of the 18th biennial southern silvicultural research conference. USDA Forest Service e-General Technical Report SRS-212, ed. C.J. Schweitzer, W.K. Clatterbuck, and C.M. Oswalt. Asheville: USDA Forest Service, Southern Research Station.

Lamont, B.B., N.J. Enright, and T. He. 2011. Fitness and evolution of resprouters in relation to fire. Plant Ecology 212: 1945-1957 https://doi.org/10.1007/s11258011-9982-3.

LaPointe, L., J. Bussieres, M. Crete, and J.-P. Ouellet. 2010. Impact of growth form and carbohydrate reserves on tolerance to simulated deer herbivory and subsequent recovery in Lilliaceae. American Journal of Botany 97: 913-924 https://doi.org/10.3732/ajb.0900200.

Lavoie, M., G. Starr, M.C. Mack, T.A. Martin, and H.L. Gholz. 2010. Effects of a prescribed fire on understory vegetation, carbon pools, and soil nutrients in a longleaf pine-slash pine forest in Florida. Natural Areas Journal 30: 82-94 https://doi.org/10.3375/043.030.0109.

Lloret, F., and L. Lopez-Soria. 1993. Resprouting of Erica multiflora after experimental fire treatments. Journal of Vegetation Science 4: 367-374 https:// doi.org/10.2307/3235595.

Maguire, A.J., and E.S. Menges. 2011. Post-fire growth strategies of resprouting Florida scrub species. Fire Ecology 7: 12-25 https://doi.org/10.4996/ fireecology.0703012.

Martinez-Vilalta, J., A. Sala, D. Asensio, L. Galiano, G. Hoch, S. Palacio, F.I. Piper, and F. Lloret. 2016. Dynamics of non-structural carbohydrates in terrestrial plants: a global synthesis. Ecological Monographs 86: 495-516 https://doi.org/10. 1002/ecm.1231.

Mauchly, J.W. 1940. Significance test for sphericity of a normal $n$-variate distribution. The Annals of Mathematical Statistics 11 (2): 204-209 https://doi. org/10.1214/aoms/1177731915.

McKinley, D.C., J.C. Romero, B.A. Hungate, B.G. Drake, and J.P. Megonigal. 2009. Does deep soil $\mathrm{N}$ availability sustain long-term ecosystem responses to elevated $\mathrm{CO}_{2}$ ? Global Change Biology 15: 2035-2048 https://doi.org/10.1111/j. 1365-2486.2008.01836.x.

Menges, E.S. 1999. Ecology and conservation of Florida scrub. In The savanna, barren, and rock outcrop communities of North America, ed. R.C. Anderson, J.S. Fralish, and J. Baskin, 7-22. Cambridge: Cambridge University Press https:// doi.org/10.1017/CBO9780511574627.002.

Menges, E.S. 2007. Integrating demography and fire management: an example from Florida scrub. Australian Journal of Botany 55: 261-272 https://doi.org/ 10.1071/BT06020.

Menges, E.S., and N.M. Kohfeldt. 1995. Life history strategies of Florida scrub plants in relation to fire. Bulletin of the Torrey Botanical Club 122 (4): 282-297 https://doi.org/10.2307/2996320.

Menges, E.S., K.N. Main, R.L. Pickert, and K. Ewing. 2017. Evaluation of a fire management plan for fire regime goals in a Florida landscape. Natural Areas Journal 37: 212-227 https://doi.org/10.3375/043.037.0210.

Menges, E.S., and S.A. Smith. 2019. Predicting aboveground biomass for Florida scrub plants. Florida Scientist 82: 63-72.

Menges, E.S., P.F. Quintana-Ascencio, C.W. Weekley, and O.G. Gaoue. 2006. Population viability analysis and fire return intervals for an endemic Florida scrub mint. Biological Conservation 127: 115-127 https://doi.org/10.1016/j. biocon.2005.08.002.

Michielsen, M., L. Szernmak, A. Fenesi, I. Nijs, and E. Ruprecht. 2017. Resprouting of woody species encroaching temperate European grasslands after cutting and burning. Applied Vegetation Science 20: 388-396 https://doi.org/10.1111/ avsc. 12300

Miranda, K.M., M.G. Espey, and D.A. Wink. 2001. A rapid, simple spectrophotometric method for simultaneous detection of nitrate and nitrite. Nitric Oxide 5: 62-71 https://doi.org/10.1006/niox.2000.0319.

Moreira, B., J. Tormo, and J.G. Pausas. 2012. To resprout or not to resprout: factors driving intraspecific variability in resprouting. Oikos 121: 1577-1584 https:// doi.org/10.1111/j.1600-0706.2011.20258.x. 
Moreno, J.M., and W.C. Oechel. 1991. Fire intensity and herbivory effects on postfire resprouting of Adenostema fasciculatum in southern California chaparral. Oecologia 85: 429-433 https://doi.org/10.1007/BF00320621.

Morris, D. 1948. Quantitative determination of carbohydrates with Dreywood's anthrone reagent. Science 107: 254-255 https://doi.org/10.1126/science.107. 2775.254 .

Mulvaney, R.L. 1996. Nitrogen-inorganic forms. In Methods of soil analysis. Part 3-chemical methods, ed. J.M. Bartels, D.L. Sparks, A.L. Page, P.A. Helmke, R.H. Loeppert, P.N. Soltanpour, M.A. Tabatabai, C.T. Johnston, and M.E. Sumner, 1123-1184. Madison: Soil Science Society of America, Inc.

Myers, R.L. 1985. Fire and the dynamic relationship between Florida sandhill and sand pine scrub vegetation. Bulletin of the Torrey Botanical Club 112: 241-252 https://doi.org/10.2307/2996539.

Nelson, D.W., and L.E. Sommers. 1996. Total carbon, organic carbon, and organic matter. In Methods of soil analysis. Part 3-chemical methods, ed. J.M. Bartels, D.L. Sparks, A.L. Page, P.A. Helmke, R.H. Loeppert, P.N. Soltanpour, M.A. Tabatabai, C.T. Johnston, and M.E. Sumner, 961-1010. Madison: Soil Science Society of America, Inc.

Nicholson, A., L.D. Prior, G.L.W. Perry, and D.M.J.S. Bowman. 2017. High post-fire mortality of resprouting woody plants in Tasmanian mediterranean-type vegetation. International Journal of Wildland Fire 26: 532-537 https://doi.org/ 10.1071/WF16211.

Noble, J.C., and P.J. Diggle. 2014. Population biology of coppicing plants: a survival of mallee (Eucalyptus spp.) populations exposed to contrasting fire and cutting regimes. Australian Journal of Botany 61: 552-557 https://doi.org/ 10.1071/BT13141.

Noss, R.F. 2018. Fire ecology of Florida and the Southeastern Coastal Plain. Gainesville: University Press of Florida.

Olano, J.M., E.S. Menges, and E. Martinez. 2006. Carbohydrate storage patterns in five resprouting scrub plants across a fire gradient. New Phytologist 170: 99-106 https://doi.org/10.1111/j.1469-8137.2005.01634.x.

Paula, S., and F. Ojeda. 2006. Resistance of three co-occurring resprouter Erica species to highly frequent disturbance. Plant Ecology 183: 329-336 https:// doi.org/10.1007/s11258-005-9043-x.

Paula, S., and F. Ojeda. 2009. Belowground starch consumption after recurrent severe disturbance in three resprouting species of the genus Erica. Canadian Journal of Botany 87: 253-259 https://doi.org/10.1139/B08-134.

Pausas, J.G., R.A. Bradstock, D.A. Keith, and J.E. Keeley. 2004. Plant functional traits in relation to fire in crown-fire ecosystems. Ecology 85: 1085-1100 https://doi. org/10.1890/02-4094.

Pausas, J.G., B.B. Lamont, S. Paula, B. Appezzato-da-Gloria, and A. Fidelis. 2018. Unearthing belowground bud banks in fire-prone ecosystems. New Phytologist 217: 1435-1448 https://doi.org/10.1111/nph.14982.

Peguero, G., and J.M. Espelta. 2011. Disturbance intensity and seasonality affect the resprouting ability of the neotropical dry-forest tree Acacia pennatula: do resources stored below-ground matter? Journal of Tropical Ecology 27: 539-546 https://doi.org/10.1017/S0266467411000290.

Peterson, S.M., and P.B. Drewa. 2014. Effects of biennial fire and clipping on woody and herbaceous ground layer vegetation: implications for restoration and management of oak barren ecosystems. Restoration Ecology 22: 525-533 https://doi.org/10.1111/rec.12102.

Platt, W.J., S.L. Orzell, and M.G. Slocum. 2015. Seasonality of fire weather strongly influences fire regimes in south Florida savanna-grassland landscapes. PLoS ONE 10 (1): e0116952 https://doi.org/10.1371/journal.pone.0116952.

Poorter, L., K. Kitajima, P. Mercado, J. Chubina, I. Melgar, and H.H.T. Prins. 2010. Resprouting as a persistence strategy of tropical forest trees: relations with carbohydrate storage and shade tolerance. Ecology 91: 2613-2627 https://doi. org/10.1890/09-0862.1.

Potvin, C., M.J. Lechowicz, and S. Tardif. 1990. The statistical analyses of ecophysiological response curves obtained from experiments involving repeated measures. Ecology 71: 1389-1400 https://doi.org/10.2307/1938276

Robbins, L.E., and R.L. Myers. 1992. Seasonal effects on prescribed burning in Florida: a review. Tall Timbers Research, Inc., miscellaneous publication. Tallahassee: Tall Timbers Research Station.

Roques, K.G., T.G. O'Connor, and A.R. Watkinson. 2001. Dynamics of shrub encroachment in an African savanna: relative influences of fire, herbivory, rainfall and density dependence. Journal of Applied Ecology 38: 268-280 https://doi.org/10.1046/j.1365-2664.2001.00567.x.

Russell-Smith, J., P.G. Ryan, and D.C. Cheal. 2002. Fire regimes and the conservation of sandstone heath in monsoonal northern Australia: frequency, interval, patchiness. Biological Conservation 104: 91-106 https://doi.org/10.1016/S0006-3207(01)00157-4.
Saha, S., A. Catenazzi, and E.S. Menges. 2010. Does time since fire explain plant biomass distribution in the Florida, USA, scrub ecosystem? Fire Ecology 6 (2): 13-25 https://doi.org/10.4996/fireecology.0602013.

Sardans, J., J.J. Penuelas, and F. Roda. 2006. The effects of nutrient availability and removal of competing vegetation on resprouters capacity and nutrient accumulation in the shrub Erica multiflora. Acta Oecologica 29: 221-232 https://doi.org/10.1016/j.actao.2005.10.006.

Schafer, J.L., and M.G. Just. 2014. Size dependency of post-disturbance recovery of multi-stemmed resprouting trees. PLoS One 9 (8): e105600.

Schafer, J.L., and M.C. Mack. 2010. Short-term effects of fire on soil and plant nutrients in palmetto flatwoods. Plant and Soil 334: 433-447 https://doi.org/ 10.1007/s11104-010-0394-2

Schafer, J.L., and M.C. Mack. 2013. Effects of time-since-fire on soil nutrient dynamics in Florida scrubby flatwoods. Florida Scientist 76: 417-435 https:// doi.org/10.1371/journal.pone.0105600.

Schafer, J.L., and M.C. Mack. 2018. Nutrient limitation of plant productivity in scrubby flatwoods: does fire shift nitrogen versus phosphorus limitation? Plant Ecology 219: 1063-1079 https://doi.org/10.1007/s11258-018-0859-6.

Schmalzer, P.A. 2003. Growth and recovery of oak-saw palmetto scrub through ten years after fire. Natural Areas Journal 23: 5-13.

Schmalzer, P.A., and C.R. Hinkle. 1992. Recovery of oak-saw palmetto scrub after fire. Castanea 57: 158-173.

Schmalzer, P.A., and C.R. Hinkle. 1996. Biomass and nutrients in aboveground vegetation and soils of Florida oak-saw palmetto scrub. Castanea 61: 168-193.

Schutz, A.E.N., W.J. Bond, and M.D. Cramer. 2009. Juggling carbon: allocation patterns of a dominant tree in a fire-prone savanna. Oecologia 160: 235-246 https://doi.org/10.1007/s00442-009-1293-1.

Sims, G.K., T.R. Ellsworth, and R.L. Mulvaney. 1995. Microscale determination of inorganic nitrogen in water and soil extracts. Communications in Soil Science and Plant Analysis 26: 303-316 https://doi.org/10.1080/00103629509369298.

Smith, D.M., D.M. Finch, C. Gunning, R. Jemison, and J.F. Kelly. 2009. Post-fire recovery of riparian vegetation during a period of water scarcity in the southwestern USA. Fire Ecology 5 (1): 38-55 https://doi.org/10.4996/ fireecology.0501038.

Swain, H. 1998. Archbold Biological Station and the MacArthur Agro-Ecology Research Center. Bulletin of the Ecological Society of America 79: 114-120.

Thaxton, J.M., and W.J. Platt. 2006. Small-scale fuel variation alters fire intensity and shrub abundance in a pine savanna. Ecology 87: 1331-1337 https://doi. org/10.1890/0012-9658(2006)87[1331:SFVAFI]2.0.CO;2.

Thomas, G.W. 1996. Soil pH and soil acidity. In Methods of soil analysis. Part 3-chemical methods, ed. J.M. Bartels, D.L. Sparks, A.L. Page, P.A. Helmke, R.H. Loeppert, P.N. Soltanpour, M.A. Tabatabai, C.T. Johnston, and M.E. Sumner, 475-490. Madison: Soil Science Society of America, Inc.

Tolsma, A.D., K.G. Tolhurst, and S.M. Read. 2010. Effects of fire, post-fire defoliation, drought and season on regrowth and carbohydrate reserves of alpine snowgrass Poa fawcettiae (Poaceae). Australian Journal of Botany 58: 157-168 https://doi.org/10.1071/BT09186.

Turner, W.R., D.S. Wilcove, and H.M. Swain. 2006. Assessing the effectiveness of reserve acquisition programs in protecting rare and threatened species. Conservation Biology 20: 1657-1669 https://doi.org/10.1111/j.1523-1739.2006. 00536.x.

Van Nieuwstdt, M.G., and D. Sheil. 2005. Drought, fire and tree survival in a Borneo rain forest, East Kalimantan, Indonesia. Journal of Ecology 93: 191-201 https://doi.org/10.1111/j.1365-2745.2004.00954.x.

Vesk, P.A., D.I. Warton, and M. Westoby. 2004. Sprouting by semi-arid plants: testing a dichotomy and predictive traits. Oikos 107: 72-89 https://doi.org/10. 1111/j.0030-1299.2004.13122.x.

von Arx, G., A. Arzac, P. Fonti, D. Frank, R. Zweifel, A. Rigling, L. Galiano, A. Gessler, and J.M. Olano. 2017. Responses of sapwood ray parenchyma and nonstructural carbohydrates of Pinus sylvestris to drought and long-term irrigation. Functional Ecology 31: 1371-1382 https://doi.org/10.1111/13652435.12860.

von Ende, C.N. 1993. Repeated-measures analysis: growth and other timedependent measures. In Design and analysis of ecological experiments, ed. S. M. Scheiner and J. Gurevitch, 113-137. New York: Chapman and Hall.

Wally, A., E.S. Menges, and C.W. Weekley. 2006. Comparison of three devices for estimating fire temperatures in ecological studies. Applied Vegetation Science 9: 97-108 https://doi.org/10.1111/j.1654-109X.2006.tb00659.x.

Weekley, C.W., E.S. Menges, and R.L. Pickert. 2008. An ecological map of Florida's Lake Wales Ridge: a new boundary delineation and an assessment of postColumbian habitat loss. Florida Scientist 71: 45-64. 
Wigley, B.J., M.D. Cramer, and W.J. Bond. 2009. Sapling survival in a frequently burnt savanna: mobilisation of carbon reserves in Acadia karroo. Plant Ecology 203: 1-11 https://doi.org/10.1007/s11258-008-9495-x.

Zeppel, M.J.B., S.P. Harrison, H.D. Adams, D.I. Kelley, G. Li, D.T. Tissue, T.E. Dawson,

R. Fensham, B.E. Medlyn, A. Palmer, A.G. West, and N.G. McDowell. 2015.

Drought and resprouting plants. New Phytologist 206: 583-589 https://doi. org/10.1111/nph.13205.

\section{Publisher's Note}

Springer Nature remains neutral with regard to jurisdictional claims in published maps and institutional affiliations.

\section{Submit your manuscript to a SpringerOpen ${ }^{\circ}$} journal and benefit from:

- Convenient online submission

Rigorous peer review

- Open access: articles freely available online

High visibility within the field

- Retaining the copyright to your article

Submit your next manuscript at $\boldsymbol{\wedge}$ springeropen.com 